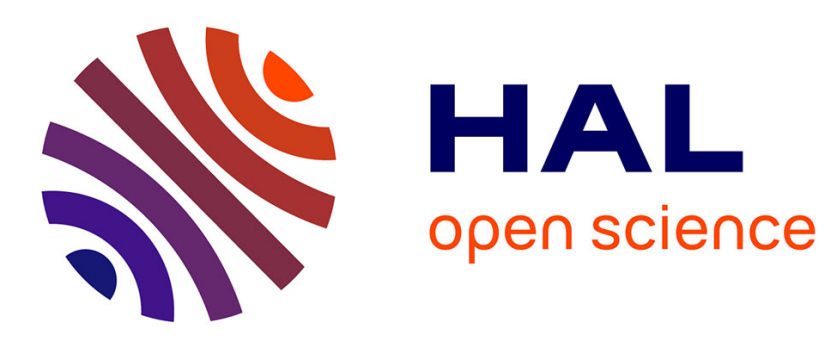

\title{
Extended and revised archaeomagnetic database and secular variation curves from Bulgaria for the last eight millennia
}

Meri Kovacheva, M. Kostadinova-Avramova, N. Jordanova, Philippe Lanos, Y. Boyadzhiev

\section{To cite this version:}

Meri Kovacheva, M. Kostadinova-Avramova, N. Jordanova, Philippe Lanos, Y. Boyadzhiev. Extended and revised archaeomagnetic database and secular variation curves from Bulgaria for the last eight millennia. Physics of the Earth and Planetary Interiors, 2014, 236, pp.79-94. 10.1016/j.pepi.2014.07.002 . insu-01130223

\section{HAL Id: insu-01130223 \\ https://hal-insu.archives-ouvertes.fr/insu-01130223}

Submitted on 11 Mar 2015

HAL is a multi-disciplinary open access archive for the deposit and dissemination of scientific research documents, whether they are published or not. The documents may come from teaching and research institutions in France or abroad, or from public or private research centers.
L'archive ouverte pluridisciplinaire HAL, est destinée au dépôt et à la diffusion de documents scientifiques de niveau recherche, publiés ou non, émanant des établissements d'enseignement et de recherche français ou étrangers, des laboratoires publics ou privés. 


\section{Extended and Revised Archaeomagnetic Database and Secular Variation Curves from Bulgaria for the Last Eight Millennia}

M. Kovacheva ${ }^{a}$, M. Kostadinova-Avramova ${ }^{a}$, 'N. Jordanova ${ }^{a}$, Ph Lanos, and Y. Boyadzhiev $^{c}$

${ }^{a}$ National Institute of Geophysics, Geodesy and Geography, Bulgarian Academy of Sciences, Acad. G. Bonchev Str., bl.3, 1113 Sofia, Bulgaria, e-mail: marykov@abv.bg, miki4740@abv.bg; vanedy@geophys.bas.bg

b Université de Rennes 1 "Géosciences-Rennes", Bât. 15, Equipe "Paléo-Archéomagnétisme" Campus scientifique de Beaulieu, CS 74205, 35042 RENNES Cedex, e-mail: philippe.lanos@univ-rennes1.fr

${ }^{c}$ National Institute of Archaeology and Museum, Bulgarian Academy of Sciences, Saborna Str. 2, 1000 Sofia, Bulgaria, e-mail: yavordb@abv.bg

Corresponding author: Maria Kostadinova-Avramova; miki4740@abv.bg; Acad. G. Bonchev Str., bl.3, 1113 Sofia, Bulgaria; +359 895745 533; +3592979 3327

\section{ABSTRACT}

The efforts of geophysicists to describe geomagnetic field behaviour in the past lead to creation of different geomagnetic field models. On the other hand, the established regional palaeosecular variations of geomagnetic elements are increasingly used for dating purposes in archaeology. Both of these goals can be achieved if sufficient amounts of long archaeomagnetic data sets exist for different geographical regions. The accumulation of archaeomagnetic determinations began at the middle of the last century, parallel with the progressive development of experimental methodology and acceptance criteria. The presence of great number of old determinations requires their critical assessment. The important question about the 
reliability of the associated dating intervals should be also re-assessed. All this requires the continuous refinement and extension of the accumulated databases. This paper presents the last synthesis of Bulgarian archaeomagnetic database and the local palaeosecular variation curves obtained using a statistical treatment based on Bayesian approach (RenCurve software). The rock-magnetic characteristics of the newly included, non-published results are summarized.

Key words: archaeomagnetism, database, southeastern Europe, reference curves

\section{Introduction}

Archaeological baked clay structures and volcanic rocks are the most valuable source of data bearing information about the past behaviour of full geomagnetic vector. On the basis of this kind of data, treated with Bayesian (Lanos, 2004; Lanos et al., 2005; Lanos et al., in preparation) or bivariate (Le Goff et al., 2002) statistics, enable secular variation curves (SVCs) to be built for a given territory. These curves should be created from sufficiently precise archaeomagnetic determinations obtained from well dated materials preferably by independent methods. In such cases, SVCS can be used in archaeology for dating purposes (Kovacheva et al., 2004; Lanos, 2004; Herve et al., 2011). The global and regional geomagnetic field modeling (Korte et al., 2009; Korte and Constable, 2011; Pavón-Carrasco et al., 2009) is the most important key for elucidating the geomagnetic field origin and fluid motions in the Earth`s interior. These complicated geophysical problems can be solved on the basis of reliable data sets of archaeomagnetic and palaeomagnetic (volcanic and sedimentary environments) determinations of geomagnetic field elements. Each database 
compilation is a long, continuous process and periodical updates, revision or reexaminations are required. The accumulation of the Bulgarian data set started in 1967 and several updates have been published (Kovacheva, 1992; Kovacheva, 1997; Kovacheva et al., 2009a). In previous compilations archaeomagnetic determination from all studied collections in Sofia Palaeomagnetic laboratory (Bulgarian, Serbian, Greek, etc) were included. Now the data from non-Bulgarian archaeological sites are excluded and those obtained after 2009 (28 different features) are added. Furthermore, in the present compilation, the dating intervals for some sites were corrected according to the new ${ }^{14} \mathrm{C}$ dates that are becoming available or last archeological conceptions. The aim of this paper is to communicate the enlarged and revised after 2009 local data set and the obtained from it local reference curves for the three geomagnetic field elements during the last 8000 years.

\section{General description of the extended database}

The basic feature of Bulgarian archaeomagnetic data set is that it summarizes the simultaneous determination of the geomagnetic field direction $(D, I)$ and intensity (F) - both parameters being obtained from the same material. It covers almost the entire prehistoric and historic periods. The methodology applied in the Sofia Palaeomagnetic laboratory was gradually improved and optimized over the years. Detailed information about sampling technique, experimental protocols, selection and quality criteria can be found in Kovacheva and Toshkov (1994), Kovacheva et al. (1998), Kovacheva et al. (2009a), Kostadinova-Avramova et al. (2014). The archaeomagnetic determination correspond to the feature`s mean values as "the feature is a volume of material that can be considered to have been magnetized at the same time" (Tarling, 
1983). In some cases (mainly for the historic periods) "feature" coincides with the studied site, but in other (e.g. for the prehistoric periods), several "features" corresponding to different layers are related to the same archaeological site. The feature's average values for the direction are calculated following the hierarchical approach (Lanos et al., 2005).

The used ${ }^{14} \mathrm{C}$ dates (generally series of ${ }^{14} \mathrm{C}$ dates) were taken mainly from Görsdorf and Bojadžiev (1996). Most of these were obtained by the conventional method and OxCal 4.0 software was used for their calibration. The recently received ${ }^{14} \mathrm{C}$ dates for some prehistoric archaeological sites by the AMS method were compared with those obtained by the conventional method. The both methods give consistent results (Boyadzhiev, in press). The problems concerning ${ }^{14} \mathrm{C}$ dates related to Eneolithic period are described in Boyadziev (1995) and Kostadinova-Avramova et al. (2014). When there are no ${ }^{14} \mathrm{C}$, the archaeological assumption about the dating interval is based on stratigraphic constraints, e.g., the accumulation rate of layer and the cultural features found in it. Often, in addition to the existing ${ }^{14} \mathrm{C}$ dates, the mentioned archaeological evidences and the type of material (annual or perennial) used for ${ }^{14} \mathrm{C}$ dating were taken into account, which has led to better constraint of the dating intervals.

\section{Please, insert the Table here}

The archaeomagnetic data and all supporting information are given in a Table. For clarity the same format is kept as the Table linked to Kovacheva et al., 2009a. The differences are listed below:

- 28 newly included Bulgarian sites (given in bold). 
- All the data obtained from non-Bulgarian sites (Serbian, Greek, etc) but studied in Sofia laboratory were excluded. Thus the column "Country" becomes unnecessary and it is discarded. The Serbian data were used previously for the construction of first local SVCs in Kovacheva and Toshkov, 1994 and Kovacheva et al., 1998.

- Another discarded column is "STEP" connected with the level of the thermal or alternating field cleaning. The normalized palaeointensity (PI) results corresponding to the site dipole field (PI_PIDIP) were also excluded.

- A new column for " $K$ " was added. This column represents the grouping factor according to the Fisher (1953) statistics.

- When no data were available, the sign "*" was used in the Table.

- The results of inclination (I) of many sites represented only by brick materials were re-evaluated (e.g. Labnos 107, 108, 141) and some were discarded (e.g. these of Labnos 202, 230, 271) keeping only the intensity results.

- At the end there were 32 reference sites for which a new evaluation of the directional results (I and $\mathrm{D}$ ) or only of the PI result had been performed (e.g. Labnos 36, 113, 156, 227, 311). The directional results for Labno 85 were discarded. This site has been studied at least 40 years ago and a doubt existed for the reliability of the results obtained on the basis of very limited number of independently oriented samples. 
- Labno 97 (Kovacheva et al., 2009a) was entirely discarded because of its dubious results. Now the same Labno 97 was given to the results of one unused so far sector from the multilevel Bronze tell at Dyadovo.

- Two Labnos 10 and 294 from Kovacheva et al. (2009a), representing averaged results from successive layers in the sites Samovodene and Koprivetz, correspondingly were changed. They were both separated following the stratigraphy and the advices of archaeologists. Thus three new reference points: Labnos 354, 355 and 358 were obtained.

- For the prehistoric past the newly obtained ${ }^{14} \mathrm{C}$ dates were taken (e.g. Labnos $247,261,272)$. It should be noticed that for the sites dated on the basis of ${ }^{14} \mathrm{C}$ only, the dating intervals are now given exactly on the $95.4 \%$ probability level. This interval is often very large but is required for the subsequent mathematical applications. In some cases taking these large intervals, their midpoints are not always consistent with the stratigraphy (e.g. Labnos 306; 307; 295) Dating intervals of some prehistoric sites (layers) without ${ }^{14} \mathrm{C}$ were changed according to the last archaeological conceptions related to the stratigraphic constraints and cultural features (e.g. Labnos 50, 281, 295).

- For the prehistoric past the column showing the stratigraphic constraints is added (SC). Older/current Labno is after the "older» and before the "younger»/younger (e.g. 35/51/52) for Labno 51. The information in this column clarifies the above mention problem when considering only the midpoints. 
- Besides the problems in prehistory, the dates of several Middle age sites were changed after new consultations with the archaeologists (e.g. Labnos 120, 159, 195, 314).

\section{General magnetic characteristics of the unpublished sites, included after 2009}

The new sites included in the last version of Bulgarian database are 28 . The archaeomagnetic results from 11 of them are published (corresponding references are given in the last column of the Table - the first reference corresponds to that of Geomagia 50.v3 (in preparation) and the second one corresponds to the original (detailed) publication). The main properties of the other 17 unpublished reference points are summarized in this section.

For all studied materials different types of magnetic cleaning were performed. Viscous cleaning was done for all specimens coming from the gathered hand samples. The viscosity coefficient Sv (\%) was calculated for each specimen according to the relation Sv $\left.=\left\{\mathrm{NRM}_{0}-\mathrm{NRMst}\right) / \mathrm{NRM}_{0}\right\} \times 100 \%$, where $\mathrm{NRM}_{0}$ is the initially measured remanence and NRMst is the stable component measured after the zero field storage. For the most of the studied collections acceptable $(\leq 8 \%)$ values for Sv were obtained (Fig. 1a). The exceptions are three collections (Labnos 353; 356 and 366). For these, the Sv values vary over a wide range and often exceed $8 \%$ (Fig 1b). For PI determinations only specimens with Sv less than $6 \%$ were used. There are two possible explanations for the observed high Sv values: 1) the insufficient heating in the antiquity and 2) the presence of significant amount of unstable supperparamagnetic (SP) grains. The determined $\mathrm{K}_{\mathrm{FD}}(\%)$ for the studied materials are often more than $6 \%$ (Fig 1c). This indicates that magnetic grains with SP sizes are very common for baked clay materials 
(Jordanova et al., 2001). Insufficient heating in the antiquity also is not an uncommon affecting factor - for example Labnos 368 and Labno 369 are two kilns from a recently studied archaeological site Pliska which shows high Sv and high $\mathrm{K}_{\mathrm{FD}}$ values (Kostadinova-Avramova et al., in press). On the other hand the Arai plots and magnetic susceptibilities measured after each heating step (Fig 6c) indicate that both structures have been heated in the past to temperatures around $430-460^{\circ} \mathrm{C}$. Therefore, in this case combination of factors 1) and 2) are probably responsible for the observed high Sv values.

\section{Please, insert Fig. 1 here}

Magnetic cleaning with alternating field (AF) or temperature (Fig. 2) were applied for some selected specimens (from one to four per sample depending on the number of cut specimens). The final directional results were obtained only from the results after both $\mathrm{AF}$ and thermal cleanings.

\section{Please, insert Fig. 2 here}

Information about the domain state of the magnetic particles was obtained using the Lowrie and Fuller test (Lowrie and Fuller, 1971). The fact that the magnetite type minerals are dominant for the studied materials makes this test applicable. The test failed completely for all studied specimens related to Labno 366 where the highest amount of hematite was identified (Fig 3a). Therefore, for this site, no conclusion about the domain state of magnetic particles could be drawn. For the other sites the Lowrie and Fuller test determined that the magnetic grains had SD-like, BM or mixed behaviour of magnetic particles (Fig. 3b, c, d; Dunlop, 1983). 


\section{Please, insert Fig. 3 here}

The identification of magnetic mineralogy was based on Tb and Tc determined from three-axis isothermal remanence thermal demagnetization - 3IRM test (Lowrie, 1990) and thermomagnetic analyses respectively. The results showed a predominant presence of magnetite type magnetic minerals (titanomagnetite and/or magnetite) for all studied materials (Fig. 4). In some cases a stable in respect to temperature maghemite was also observed (Fig 4). High coercivity minerals were rather rare for the studied collections. Hematite is supposed for Labnos 349; 365 and 366 (Fig. 4b, c, f).

\section{Please, insert Fig. 4 here}

The SIRM test (Kovacheva and Jordanova, 2001; Jordanova, et al., 2003) and thermomagnetic analyses generally showed stable mineralogy of the materials during heating (Fig 4d, e, f and Fig. 5a, b). This fact makes the material especially suitable for the obtaining good PI estimations. Strong mineralogical transformations (Fig. $5 \mathrm{c}$ ) were detected only for very few individual cases (one or two specimens per collection for Labnos 351; 356; 357; 365 and 366) and usually the corresponding materials came from the external parts of the structures where probably the burning temperatures have been lower.

\section{Please, insert Fig. 5 here}

The PI experiment usually showed good internal consistency between the results and the number of failed experiments was generally less than $20 \%$ (Table columns NOPI, NPI; Fig 6a,b, c). There are two exceptions - Labnos 356 and 367 (sites Malenovo and Nessebar). The material from these two sites, in spite their stable 
mineralogy during heating, appears not appropriate for PI evaluation (Fig. 6d). On this basis no PI results were given for both of these sites.

\section{Please, insert Fig. 6 here}

For three of the newly studied features (Labnos 362; 363 and 370) it was not possible to determine the direction of the ancient geomagnetic field: Labno 362 and 370 - small number of collected pieces, characterized by a large dispersion; Labno 363 - the collection represented well burnt clay pieces found in a pit at a chaotically changed position.

\section{Discussion of the raw data}

The main difficulty in archaeomagnetic studies aiming to describe the palaeosecular variations of the geomagnetic field elements is the reliable distribution of the experimental results on the absolute scale of time (Fig. 7). This distribution depends entirely on the obtained information for dating interval of the studied structures. The last 2000 years are historically well known for the Western Europe and SVCs are obtained for France (Gallet et al., 2002) and Germany (Schnepp and Lanos, 2005). In contrast in South Europe and Asia Minor the prehistoric discoveries are very reach. The important feature of Bulgarian prehistory is the presence of multilevel settlements in which the stratigraphic chronology helps a lot the searched chronology (Kovacheva, 1995; Kostadinova-Avramova et al., 2014). Multiple revisions helped the refinement of the input data.

Please, insert Fig. 7 here 
Fig. 7 shows the unchanged raw data (I, D and F), published in Kovacheva et al., 2009a (full circles), the revised and corrected data (empty squares) and the included after 2009 new points (crosses). The principle goal of the work was to improve the quality of the data revising many of them and to increase their number as far as possible. The revised points describe better the general trend for the three geomagnetic field elements. The new results are close to the previously published (crosses in comparison with full circles).

The main drawbacks of Bulgarian database are: (a) the lack of systematic corrections for any anisotropy effect on the directional and PI results and (b) the absence of any correction for cooling rate effects on the palaeointensity. These two factors should mostly affect results from bricks and pottery. In the Bulgarian data set pottery are not included. The archaeomagnetic studies in Sofia laboratory from the beginning have been always directed to determination of full geomagnetic vector from the same material. Thus pottery has been excluded as suitable material. The one exception is Labno76 - the samples were taken from the bottom of the found in situ pithoi. The brick collections were generally studied at the beginning of the archaeomagnetic studies in Bulgaria and are from the AD time period. The laboratory field during the PI evaluation (Coe version, 1967 of Thellier and Thellier, 1959) was directed along the $z$ axis of the sample coordinate system. The difference 90 -INC is the angular deviation of the laboratory field from the carried NRM vector. As described in Kovacheva et al., (2009b) and as well known from the literature (Odah et al., 2001), this deviation is one of the main factors for the effect of the magnetic anisotropy during the $\mathrm{PI}$ evaluation. For example, on a subset of 44 brick specimens the 
anisotropy effect on the PI evaluations has been studied using the TRM anisotropy tensor (18) or the ARM anisotropy tensor (26). In 40 specimens the anisotropy correction was between $-4 \%$ and $+6 \%$ with maximum frequency being between $0 \%$ and $2 \%$. There were four cases with a higher anisotropy effect - the highest effect being $11 \%$ in one case (Fig. 8a).

\section{Please, insert Fig. 8 here}

The other deficiency of the database is the lack of cooling rate correction. Most of archaeomagnetic data were retrieved before 2004 and are based on 24 or $20 \mathrm{~mm}$ cubes that were left to cool in furnaces without a fan. The cooling time varied from two to five hours depending on the temperature. As far as the multiple data come from the often thin prehistoric ovens or floor plasters which have cooled in open air, the cooling rate effect should not be so important. However, the problem remains for the bricks in the database.

Speaking about the PI determinations and the reliability of the existing data, many authors support the idea for accepting the PI determination if the standard deviation of the average site value is no more than $5 \mu$ T (Donadini et al., 2009). The chosen threshold connected with PI values about $50 \mu \mathrm{T}$ should be quite convenient as representing $\sim 10 \%$ of the calculated average values for the corresponding sites. At the same time if the averaged palaeointensity values are between 30-35 $\mu \mathrm{T}$, the standard deviation of $5 \mu \mathrm{T}$ would represent between 17 to $14 \%$ of the mean value. Such results would be considered as very reliable data, despite having poor internal consistency. In contrast, for considerably higher average PI values ( $70 \mu \mathrm{T}$ or more) the threshold of 5 $\mu T$ would make many good evaluations as not acceptable. In our opinion, the threshold 
given to PI should be a percentage of the calculated site's average value, saying $10 \%$. Such a threshold has a similar drawback if very low palaeointensity values (less than $15 \mu \mathrm{T})$ are in question. Such low intensity values are not encountered in the archaeological past and even in the entire Holocene. Following this idea we show (Fig. $8 \mathrm{~b})$ the distribution of PI results included in the revised data set as a function of standard deviation (STD) presented as a percentage of the mean site results. Obviously a very small part of the included PI determinations have dispersion higher than $10 \%$ of the PI site's average.

\section{Bulgarian SVCs of the three geomagnetic field elements for the last $\mathbf{8 0 0 0}$ years and} discussion.

The main goal of each local data set is the elaboration of the local palaeosecular variations of the geomagnetic field elements in the archaeological past. The here presented extended and revised Bulgarian database is used to provide the searched secular variations over the last 8000 years. They are given in Fig. 9 (Lanos 2004, pp. 43-78; Lanos et al. in preparation).

\section{Please, insert Fig. 9 here}

The evident larger error bands immediately mark the time periods where not sufficient materials were found and studied (Fig. 7), due mainly to the lack of discovered sites. This problem is discussed in Kovacheva et al., 2009a. The most important gap is the so called Transition period after the end of Late Eneolithic between 3850-3750 BC and the beginning of the Bronze Age about 3200-3100/29003000 BC (Fig. 7; Fig. 9). The archaeological problem about the impossibility to accept such a discontinuity in the prehistoric development made some authors to support the 
idea for probable palaeo-climatic reason (Todorova, 1995). Middle and Late Bronze Age (around $2000 \mathrm{BC}$ ) is also insufficiently represented due to the small number of discovered sites. All these difficulties are just an example of how the archaeomagnetic studies depend on the existing archaeological problems. The revealed extreme palaeointensity value about $6^{\text {th }}-5^{\text {th }}$ century $B C$ is in good coincidence with the similar values obtained from Greek and Western Turkey materials (De Marco et al., 2008) and also with the data from Western Europe (Herve et al., 2013). The last 500 years BC are related to the existence of the rich Thracian culture in Bulgaria with much more precise archaeological dating. Thus, the observed cloud of contradictive results (Fig. 7) which determines large error bands (Fig. 9) is somehow unacceptable. The most problematic period in the palaeointensity determination is the saw type variation in the first five centuries AD. The future filling up of the present data set is of great importance for refinement of the secular variation curves and for the Earth`s magnetic field modeling.

\section{Conclusions}

As a result of this study the following conclusions can be drown:

1. Each local database requires a constant maintenance, filling up and revisions.

2. Obviously the newly obtained archaeomagnetic data are close to the previously published. The later in combination with the revised points describe better the general trend of the three geomagnetic field elements.

3. The Bayesian evaluation of the local secular variation curves of the geomagnetic elements over the last 8000 years are valuable contribution to the knowledge of past 
geomagnetic field behaviour in our lands. The obtained full geomagnetic vectors from the same materials are the best basis for the geomagnetic field modeling.

4. The accepted, as a global feature maximal PI value about $10^{\text {th }}$ century is not revealed in by our data in spite the proved important changes of geomagnetic field during the last millennia BC.

Acknowledgements: This study was supported by the Project No DMU 03/42 granted from the Bulgarian National Fund. The authors expressed their gratitude to the entire archaeological community in Bulgaria for their collaboration during sampling and for the exchange of useful information. Anonymous reviewer and Prof. Tarling are acknowledged for the valuable comments, suggestions and English style corrections.

\section{References}

Boyadziev, Y., 1995. Chronology of Prehistoric Cultures in Bulgaria, in: Bailey, D., Panayotov, I (Eds.), Prehistoric Bulgaria. Monographs in World Archaeology, No 22, pp. 149-191, Madison, Prehistory Press.

Boyadzhiev, Y., in press. Tell Yunatsite - development and absolute chronology of the settlements since the beginning of the Chalcolithic till the Early Bronze age. In: S. Hansen, P Raczky (eds.) Chronologies, Lithics and Metals. Late Neolithic and Copper Age in the eastern part of the Carpathian Basin and in the Balkans.

Coe, P.C., 1967. Palaeointensity of the Earth's magnetic field determined from tertiary and quaternary rocks. J. Geophys. Res, 72, 3247-3262. 
De Marco, E., Spatharas, V., Gómez-Paccard, M., Chauvin, A. and Kondopoulou, D., 2008. New archaeointensity results from archaeological sites and variation of the geomagnetic field intensity for the last 7 millennia in Greece. Physics and Chemistry of the Earth, Vol. 33 (6-7), 578-595.

Donadini, F., M. Korte, C. Constable, Geomagnetic Field for 0-3 ka: 1. New data sets for global modeling. Geochem. Geophys. Geosyst. 10, Q06007 (2009). doi:10.1029/2008GC002297.

Dunlop, D., 1983. Determination of domain structure in igneous rocks by alternating field and other methods. Earth Plan. Sci. Lett., 63, 353-367.

Fisher, R. A., 1953. Dispersion on a Sphere. Proc. Royal Society, London. A217, 295.

Görsdorf, J., Bojadžiev, J., 1996. Zur absoluten Chronologie der bulgarischen Urgeschichte. - Eurasia Antiqua, 2, 105-173.

Herve, G., Schnepp, E., Chauvin, A., Lanos, Ph. and Nowaczyk, N., 2011. Archaeomagnetic results on three Early Iron Age salt-kilns from Moyenvic (France). Geophys. J. Int., vol.185, issue 1, 144-156. DOI:10.1111/j.1365246X.2011.04933.

Herve, G., Chauvin, A., Lanos, Ph., 2013. Geomagnetic field variations in Western Europe from 1500 BC to 200 AD. Part II: New intensity secular variation curve. Phys. Earth Planet. Int. 218, 51-65.

Jordanova, N., Petrovski, E., Kovacheva, M. and Jordanova, D., 2001. Factors determining magnetic enhancement of burnt clay from archaeological sites. J. Archaeological Sci., 28, 1137-1148. 
Jordanova, N., Kovacheva, M., Hedley, I. and Kostadinova, M. On the suitability of baked clay for archaeomagnetic studies as deduced from detailed rockmagnetic studies. Geophys. J. Int., 2003, 153, 146-158.

Korte, M. and Constable, C., 2011. Improving geomagnetic field reconstructions for 0-3 ka. Phys. Earth Planet. Int. 188 (3-4), 247-259.

Korte, M., Donadini, F., Constable, C.G., 2009. Geomagnetic field for 0-3 ka: 2. A new series of time-varying global models. Geochem. Geophys. Geosyst., 10, Q06008, doi:10.1029/2008GC002297.

Kostadinova_Avramova, M., Kovacheva, M. and Boyadzhiev, Y., 2014. Contribution of stratigraphic constraints of Bulgarian multilevel tells in the prehistory and comparison with archaeomagnetic observations. J. Archaeol. Sci., 43, 227-238.

Kostadinova_Avramova, Lesigyarski, D., M., Kovacheva, M. in press. Archaeomagnetic study of two medieval ovens discovered in the Pliska Palace, North-eastern Bulgaria. Bulgarian e-Journal of Archaeology, vol. 4 (2014) XX-XX.

Kovacheva, M., 1992. Updated archaeomagnetic results from Bulgaria: the last 2000 years. Phys. Earth Planet. Inter., 70, No 3-4, 219-223.

Kovacheva, M., Toshkov, A., 1994. Geomagnetic field variations as determined from Bulgarian archaeomagnetic data. Part I: The last 2000 years AD. Surveys in Geophysics, 15, 673-701.

Kovacheva, M., 1995. Bulgarian archaeomagnetic studies, in: Bailey D., Panajotov I. (Eds), Prehistoric Bulgaria. Monographs in World Archaeology No 22, Prehistory Press, Madison, 209-224. 
Kovacheva, M., 1997. Archaeomagnetic database from Bulgaria: the last 8000 years. Phys. Earth Planet. Inter., 102, 145-151.

Kovacheva, M., Jordanova, N. and Karloukovski, V. 1998. Geomagnetic field variations as determined from Bulgarian archaeomagnetic data. Part II: the last 8000 years. Surveys in Geophysics, 19, 5, 413-460.

Kovacheva M., Jordanova N., 2001. Bulgarian archaeomagnetic studies: a review of methodological progress and applications in archaeology. Journal of Radioanalytical and Nuclear Chemistry, 247, 685-696.

Kovacheva, M., Hedley, I., Jordanova, N., Kostadinova, M. and Gigov, V., 2004. Archaeomagnetic dating of archaeological sites from Switzerland and Bulgaria. J. Archaeol. Sci., 31, 1463-1479.

Kovacheva, M., Boyadziev, Y., Kostadinova-Avramova, M., Jordanova, N., Donadini, F., 2009a. Updated archeomagnetic data set of the past 8 millennia from the Sofia laboratory, Bulgaria, Geochem. Geophys. Geosyst. (G3) 10, Q05002.

Kovacheva, M., Chauvin, A., Jordanova, N., Lanos, Ph. and Karloukovski, V., 2009b. Remanence anisotropy effect on the palaeointensity results obtained from various archaeological materials, excluding pottery. Earth Planets Space, 61, 711-732.

Lanos, Ph., 2004. Bayesian inference of calibration curves: application to archaeomagnetism. In: Buck, C.E., Millard, A.R. (Eds.), Tools for Constructing Chronologies: Crossing Disciplinary Boundaries. Lecture Notes in Statistics. Springer, London, pp.43-82. 
Lanos, Ph., Le Goff, M., Kovacheva, M. and Schnepp, E., 2005. Hierarchical modeling of archaeomagnetic data and curve estimation by moving average technique, Geophys. J. Int., 160, 440-476.

Lanos, Ph., Kovacheva, M., Schnepp, in preparation. Geomagnetic reference curves building using Bayesian modeling. Implications for archaeomagnetic dating. Geophys. J. Int.

Le Goff, M., Gallet, Y., Genevey, A., Warmé, N., 2002. On archaeomagnetic secular variation curves and archaeomagnetic dating. Phys. Earth Planet. Inter. 134, 203-211.

Lowrie, W. Fuller, M., 1971. On the alternating field demagnetization characteristicts of multidomain thermoremanent magnetization in magnetite. J. Geophys. Res., 76, No 26, 6339-6349.

Lowrie, W., 1990. Identification of ferromagnetic minerals in a rock by coercivity and unblocking temperature properties. Geophys. Res. Lett., 17, No 2, 159-162.

Odah, H, Hussain A.G., Hoffmann, V., Soffel, H.C., El-Gamili, M. and Deebes, H., 2001. Effect of magnetic anisotropy on the experimentally determined palaeointensity of the geomagnetic field. Earth Planets Space, 53, 363-371.

Pavón -Carrasco, F.J., Osete, M.L., Torta, J.M., Gaya-Piqué, L.R., 2009. A regional archaeomagnetic model for Europe for the last 3000 years. SCHA.DIF.3K: application to archaeomagnetic dating. Geochem. Geophys. Geosyst. 10 (3), Q03013. http://dx.doi.org/10.1029/2008GC002244. 
Tarling D. H, 1983. Paleomagnetism: Principles and Applications in Geology, Geophysics and Archaeology. Chapman and Hall, London-New York.

Thellier, E., Thellier, O., 1959. Sur l'intensite du shamp magnetique terrestre dans le passe historique et geologique. Annales de Geophysique, 15, 285-376.

Todorova, H., 1995. The Neolithic, Eneolithic and transitional period in Bulgarian prehistory, in: Bailey, D., Panayotov, I (Eds.), Prehistoric Bulgaria. Monographs in World Archaeology, No 22, pp. 79-99, Madison, Prehistory press.

\section{Appendix}

The abbreviations of the columns used in the Table are as follows:

LNO=LABNO - Identification laboratory number of the studied collection; LAT Geographical latitude of the site location; LONG - Geographical longitude of the site location; PLACE - Name of the nearest town or village to the site location; Kap. Andreevo - Kapitan Andreevo; mon. - monastery; Gol. - Golyamo; G. Kremena Gorna Kremena; SITE_HORIZ - Name of the archaeological site. Some information available as the number of the corresponding horizon, square indication and associated culture (e.g. KI - Karanovo I, KII-etc are Neolithic and Eneolithic culture related to Bulgarian relative chronology); L. - Late; E. - Early; M. - Middle; EB - Early Bronze; Eneol. - Eneolithic; LE - Late Eneolithic; ME - Middle Eneolithic; EE - Early Eneolithic; TP - Transition period; LN - Late Neolithic; c. - century; ch. - church; cer. ceramic; St. - Saint; sq - square; Med. - Medieval; Bogor. - Bogoroditza; mat. material; dwell. - dwelling; West. - Western; Chr. - Christian; amphith. amphitheater; hor. - horizon; dwrd or upwrd - the horizons in multilevel prehistoric 
settlements are counted downward or upward respectively; Multil. - multilevel; Trans. - transition; per. - period, lev. - level; beg. - beginning; Supp. - supposed; cult. culture; equipm. - equipment; settl. - settlement; sect. - sector; MAT=MATERIAL Type of the used material or structure sampled: BR - brick as displaced material; bBR burnt brick in the kiln construction; BC - baked clay; BS - burnt soil; P - pottery; KL kiln; HR - hearth or oven - thinner clay floor plaster (generally for the prehistoric sites); bST - burnt stone; BF - burnt floor; T - tile; LAGE= LOWAGE - Oldest limit of the dating interval in years (negative values for the time before Christ - BC); HAGE=HIAGE - Youngest limit of the dating interval in years (negative values for the time before Christ - BC); DTP=DTPOINT - The center of the dating interval - Midpoint; SC Stratigraphic constraints; DM=DEMAG - The magnetic cleaning used for the directional data ( $\mathrm{T}$ - thermal, $\mathrm{AF}$ - with alternating field, $\mathrm{TA}$ - thermal and alternating field); NDIR - Number of the results used for the final directional determination; DEC The value of mean declination obtained for a studied feature given in degree; INC The value of mean inclination obtained for a studied feature given in degree; $\alpha 95 \%=A L F A 95 \%$ - Semi angle of the confidence cone according to Fisher (1953), when both DEC and INC data are available; $\mathbf{K}$ - The precision parameter $\mathrm{K}$ (grouping factor) according to the Fisher statistics (1953) when both DEC and INCL are available. In the case of bricks, providing only INC, $K$ is calculated by the relation: $K=(1 / S)^{2} *(180 / \pi)^{2}$ (Lanos et al., 2005); NOPI - Number of specimens subjected to the palaeointensity determination (PI) experiment; NPI - Number of the results accepted according to the Sofia Palaeomagnetic laboratory quality criteria and used for the final mean PI determination; $\boldsymbol{\sigma}=\mathbf{S T D P I}$ - The obtained standard deviation from the weighted 
statistics. In the case of single results, the standard error of the best fitted line is given; AN_cor - When anisotropy correction for PI was studied the type of the remanence used is noted (ARM - Anhysteretic Remanent Magnetization; IRM - Isothermal Remanent Magnetization; TRM - Thermo Remanent Magnetization); TYPE - Classical Thellier and Thellier (1959) method was used from the beginning of archaeomagnetic studies in Bulgaria until 2004. After the Coe (1967) modification is applied. Taking into account that the acceptance criteria were modified and optimized during the years, different abbreviations are used for TYPE: THDL - the oldest results when PI was estimated according to the stability of direction and linearity of Arai plot; THkD - to the previous criteria the magnetic stability behaviour during heating was added; THpT - latest results - to the previous criteria pTRM tests were also included. When it appear twice, the results of classical Thellier ' method with pTRM tests were checked up with the Coe' version. When two types are noted additional check-up experiments were performed to control those obtained by older methods. The results obtained by the two methods are averaged on the basis of internal consistency, which was proved in the most cases; FLDNUMBER - Samples field numbers used for the studied feature; DATING - The independent dating method used for each feature. When ${ }^{14} \mathrm{C}$ is given in brackets (mainly for the Eneolithic period) the obtained ${ }^{14} \mathrm{C}$ dates are not taken into account due to the contradictions with vertical stratigraphy and archaeological evidences (Boyadziev, 1995). AD - Anno Domini; archaeol. - archaeological; begin. beginning; c. - century; strat. - stratigraphy; synchron. - synchronization; rel. relative; $\mathbf{R E F = R E F E R E N C E ~ - ~ T h e ~ f i r s t ~ n u m b e r s ~ g i v e n ~ i n ~ t h i s ~ c o l u m n ~ c o r r e s p o n d ~ t o ~ t h e ~}$ 
numbers in the Geomagia 50.v3 - in preparation - (http://geomagia.ucsd.edu). When the second number is 502 through it the original publications can be seen.

172 - Jordanova, N., Kovacheva, M., Kostadinova, M., 2004. Archaeomagnetic investigation and dating of Neolithic archaeological site (Kovatchevo) from Bulgaria. Phys. Earth Planet. Inter., 147, 2-3, 89-102.

173 - Herries, A.I.R., Kovacheva, M., Kostadinova, M., Shaw, J., 2007. Archaeodirectional and -intensity data from burnt structures at the Thracian site of Halka Bunar (Bulgaria): the effect of magnetic mineralogy, temperature and atmosphere of heating in antiquity. Phys. Earth Planet. Inter., 162, 3-4, 199-216.

175 - Kovacheva, M., Hedley, I., Jordanova, N., Kostadinova, M. and Gigov, V., 2004 Archaeomagnetic dating of archaeological sites from Switzerland and Bulgaria. J. Archaeological Science, 31, 1463-1479.

197 - Kovacheva, M., 1997. Archaeomagnetic database from Bulgaria: the last 8000 years. Phys. Earth Planet. Inter., 102, 145-151.

239 - this study

369 - Herries, A.I.R., Kovacheva, M., Kostadinova, M., 2008. Mineral magnetism and archaeomagnetic dating of a medieval oven from Zlatna Livada, Bulgaria. Physics and Chemistry of the Earth 33, pp 496-510.

370 - Kostadinova, M., 2009. Magnetic properties of baked clay as an object of archaeomagnetic investigations. New results in Bulgarian archaeomagnetic database. PhD thesis, BAS, 2009. 
371 - Kostadinova, M. and Kovacheva, M. Case study of the Bulgarian Neolithic Archaeological Site of Piperkov Chiflik and its archaeomagnetic dating. Physics and Chemistry of the Earth, 2008, 33, pp 511-522.

373 - Jordanova, N. and Kovacheva, M., 1998. Dating the fire in Kajmenska Chuka by the archaeomagnetic method. In: The Steps of James H. Gaul, M. Stefanovich, H. Todorova, H. Hauptmann (eds.), Series, 1, Sofia, BAS, 339-347.

502 - Kovacheva, M., Boyadziev, Y., Kostadinova-Avramova, M., Jordanova, N., Donadini, F., 2009. Updated archeomagnetic data set of the past 8 millennia from the Sofia laboratory, Bulgaria, Geochemistry Geophysics Geosystems (G3) 10, Q05002.

509 - Donadini, F., Kovacheva, M., Kostadinova-Avramova, M. Archaeomagnetic Study of Roman Lime Kilns (1 c. AD) and One Pottery Kiln (1st c. BC - 1st c. AD) at Krivina, Bulgaria, as a Contribution to Archaeomagnetic Dating. Archaeologia Bulgarica, XIV, 2 (2010), 23.38.

519 - Kostadinova-Avramova, M. Advantages and disadvantages of bricks as a material for archaeomagnetic studies, NAIM-BAS, Sofia. In press.

520 - Kovacheva, M., Kostadinova-Avramova, M., Jordanova, N., Boyadzhiev, Y., Gergova, D., Dermendjiev, N., Kancheva, T., Genov, D. Chronostratigraphy of the Dyadovo settlement mound on the basis of archaeomagnetic studies. Dyadovo Vol.2, BAS, Sofia, in press (in Bulgarian).

552 - Kostadinova_Avramova, Lesigyarski, D., M., Kovacheva, M. in press. Archaeomagnetic study of two medieval ovens discovered in the Pliska Palace, Northeastern Bulgaria. Bulgarian e-Journal of Archaeology, vol. 4 (2014) XX-XX. 
553 - Kovacheva, M. Archaeomagnetic Investigations in Bulgaria: Field Intensity determinations. Phys. Earth Planet. Inter., 13, 1977, 355-359.

554 - Kovacheva, M., Jordanova, N., Kostadinova, M., Karloukovski, V., Gigov, V., Gergova, D. and Genov, D. Summary results of the archaeomagnetic studies of the Bronze Age tell Djadovo, district of town Sliven, Bulgaria. Archaeologia Bulgarica, VI, $2002,1,1-17$.

\section{TABLE AND FIGURE CAPTION}

Table. The state of Bulgarian database related to 2014 (the detailed description of the columns is given in the Appendix). The results of sites obtained between 2009 and 2014 are given in bold. The corrected results of the presented in Kovacheva et al. (2009a) features are given in italic. All remained data are in regular font.

Fig. 1. Distribution of viscosity coefficient for representative features a) with mostly acceptable Sv(\%) values, b) with Sv values often higher than $8 \%$ and c) distributions of $\mathrm{K}_{\mathrm{FD}}(\%)$ values for three representative newly studied features.

Fig. 2. Representative examples of a) AF demagnetization and b) thermal demagnetization of the carried remanence.

Fig. 3. Representative examples of Lowrie and Fuller test showing a) the presence of high coercivity magnetic mineral (i.e. failed experiment), b) single domain (SD), c) bimodal (BM) and d) mixed behaviour of magnetic grains. 
Fig. 4. Representative examples of a), b) and c) stepwise thermal demagnetization of three components IRM (3IRM test) and d), e), f) high temperature behaviour of magnetic susceptibility - heating and cooling curves.

Fig. 5. Representative examples of SIRM test - a), b) insignificant and c) strong mineralogical changes during heating. SIRM (2T) is the isothermal remanent magnetization induced at each temperature step; SIRMleft is the remained part of the induced SIRM (2T) by the thermal demagnetization at the corresponding step; 3IRM curve is the thermal demagnetization of the module of three-axes single induced isothermal remanece (on the sister specimen), $\mathrm{K} / \mathrm{K} 20$ - normalized to the initial value magnetic susceptibility measured after each temperature step.

Fig. 6. Representative examples of a), b, c) successful and d) failed PI determination experiments.

Fig. 7. The raw data of extended and revised database. Different symbols are given to the new data, revised ones and unchanged data from Kovacheva et al., 2009.

Fig. 8. a) Distribution of anisotropy correction on PI values from an extract of 44 brick (BR) samples and b) Distribution of all PI results as a function of standard deviation expressed as a percentage of the mean PI per site.

Fig. 9 Bulgarian SVCS of the three geomagnetic field elements based on Bayesian approach (Lanos et al., in preparation). 


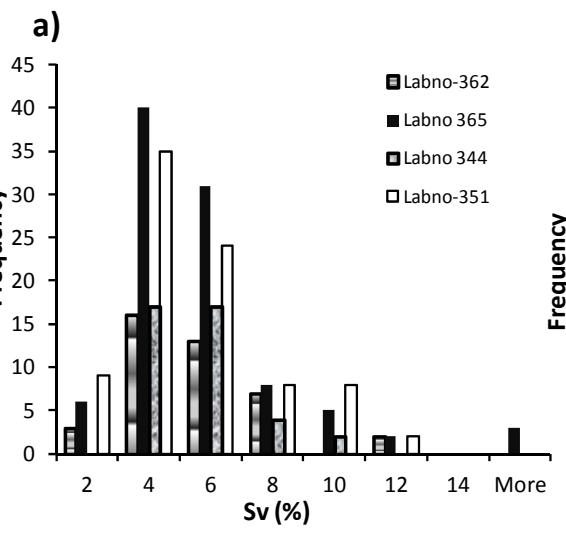

b)

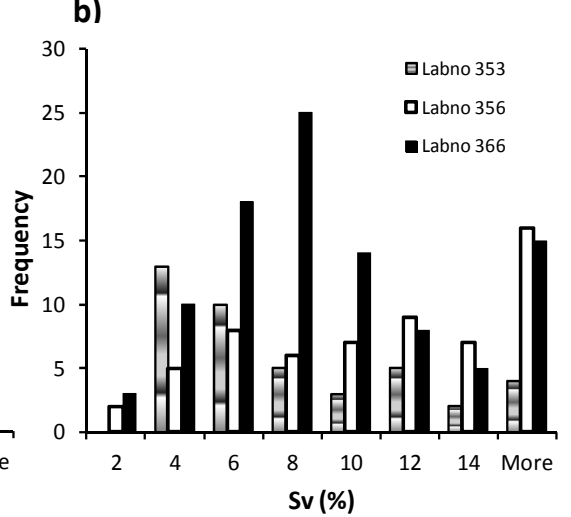

c)

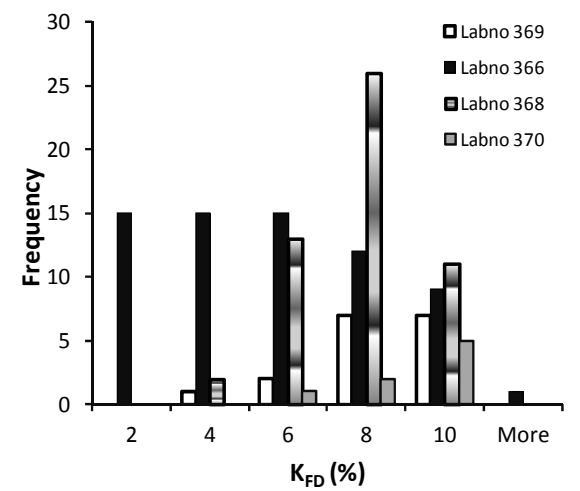

Fig. 1

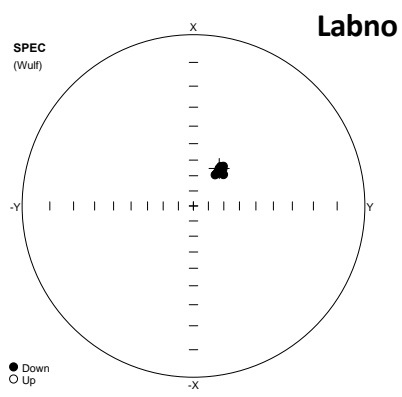

349 (2447b)
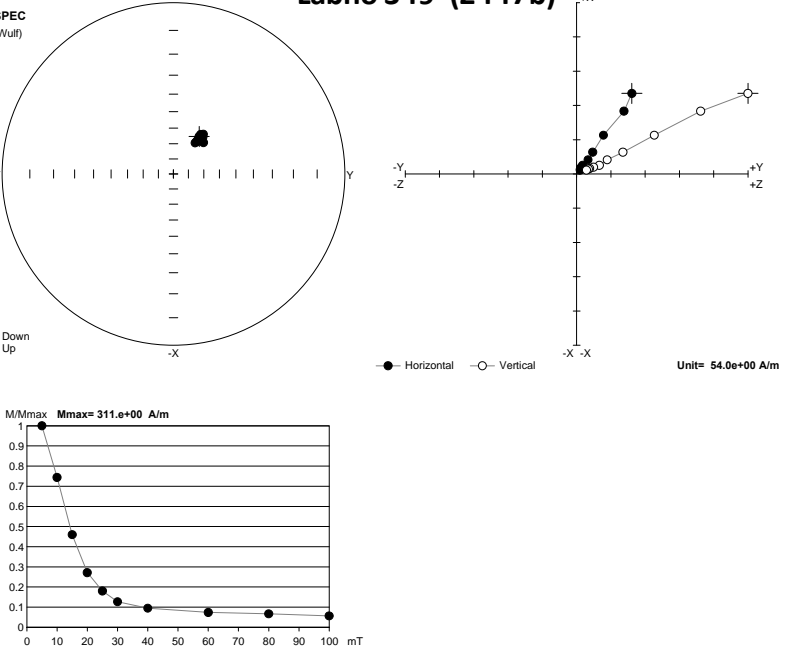
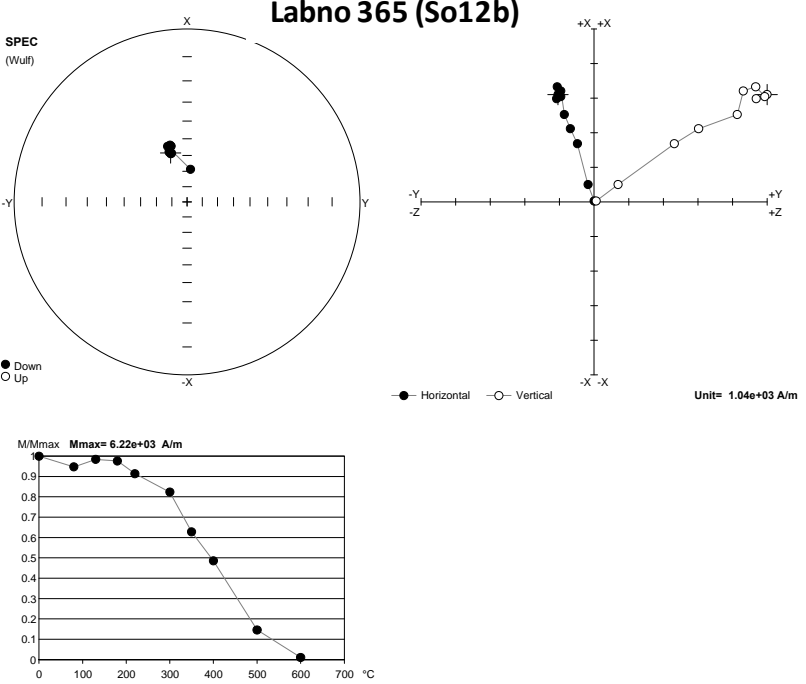

Fig. 2
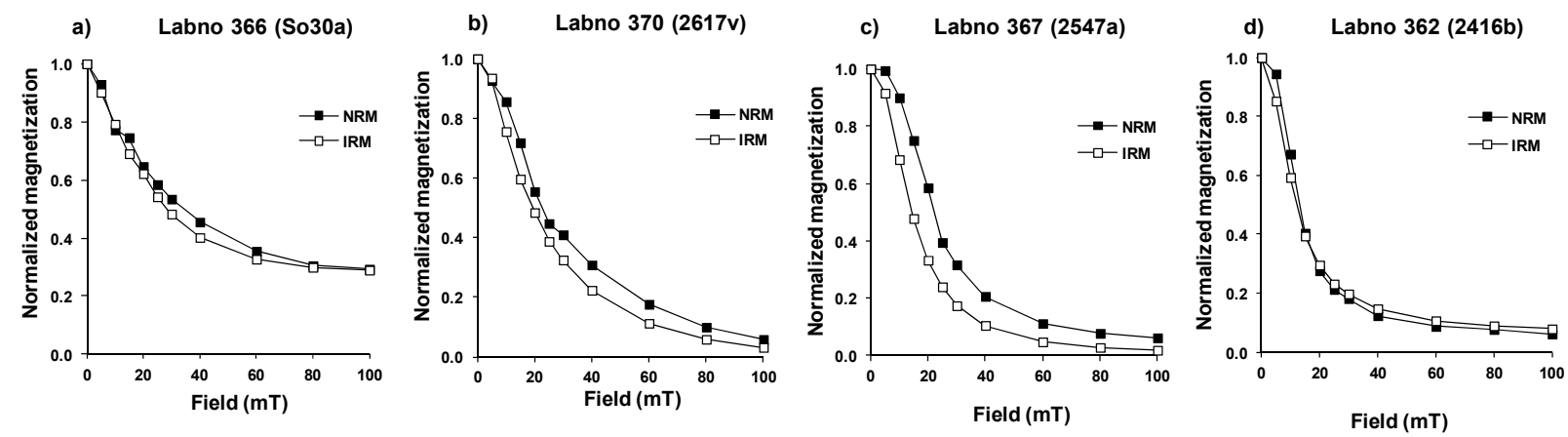

Fig. 3 

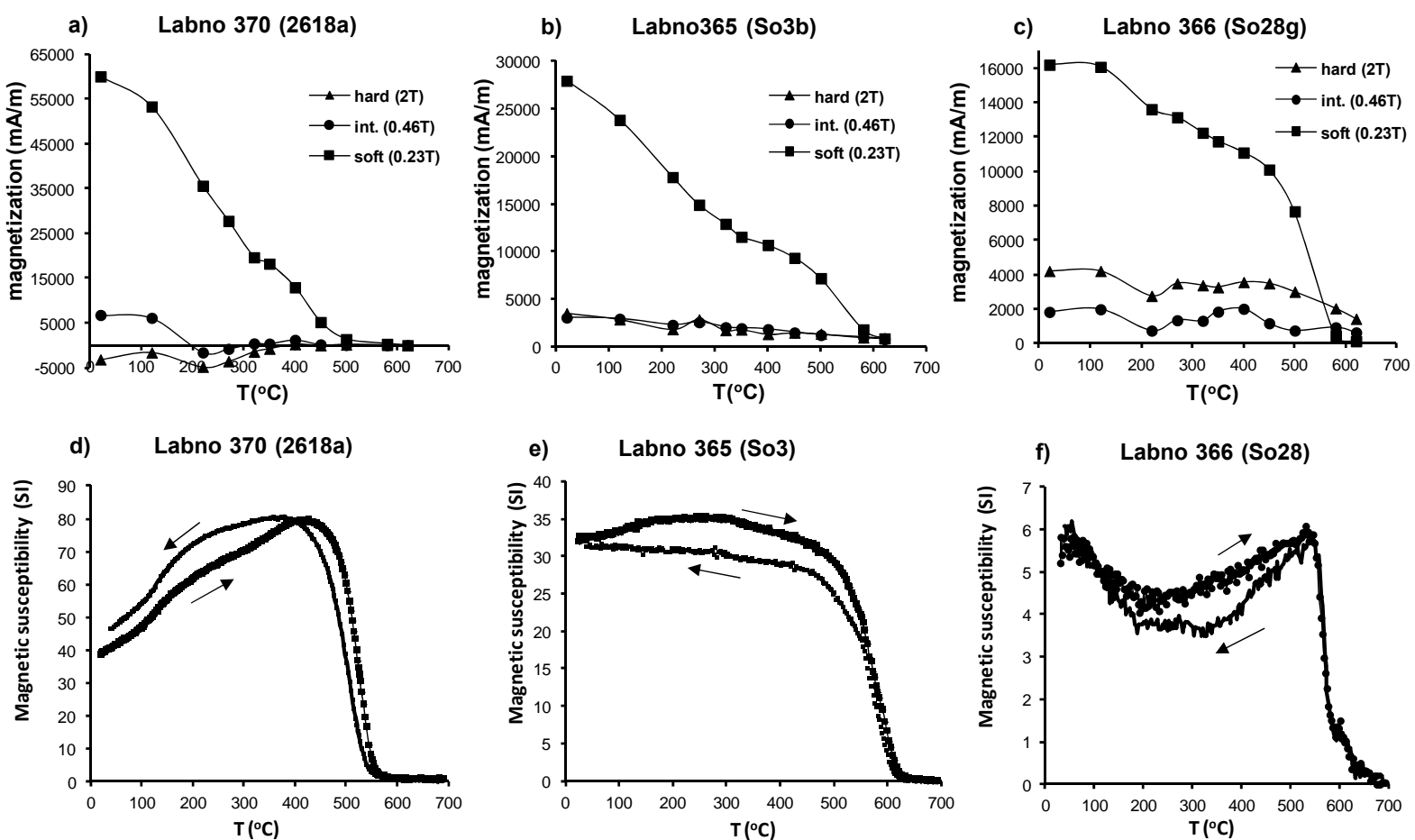

Fig. 4

a) Labno $370(2618 \mathrm{~g})$
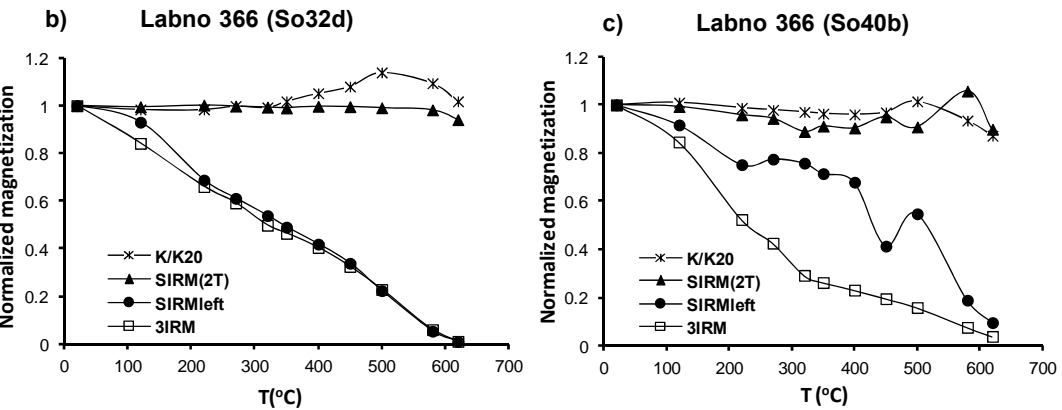

Fig. 5 
a) Labno 365 (So11a)

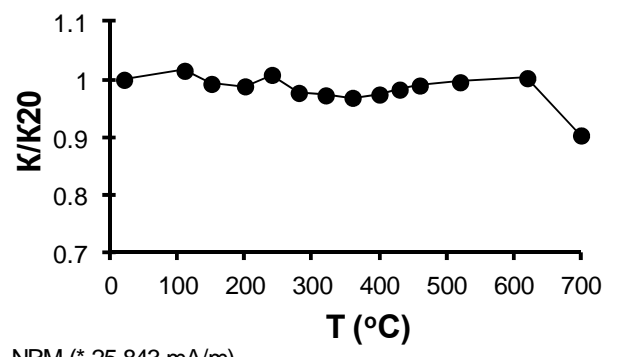

$\mathrm{NRM} \mathrm{(*} 25.843 \mathrm{~mA} / \mathrm{m})$

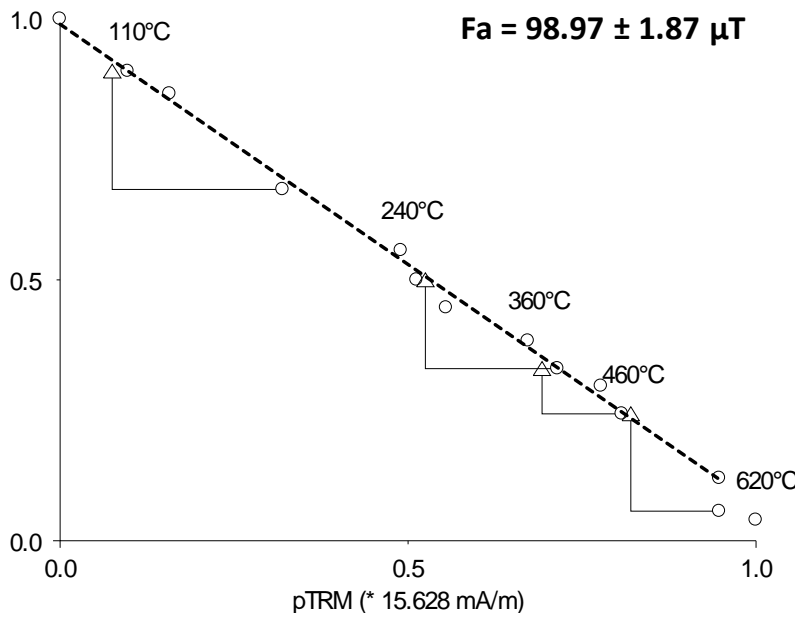

c) Labno $368(2580 \mathrm{~g})$
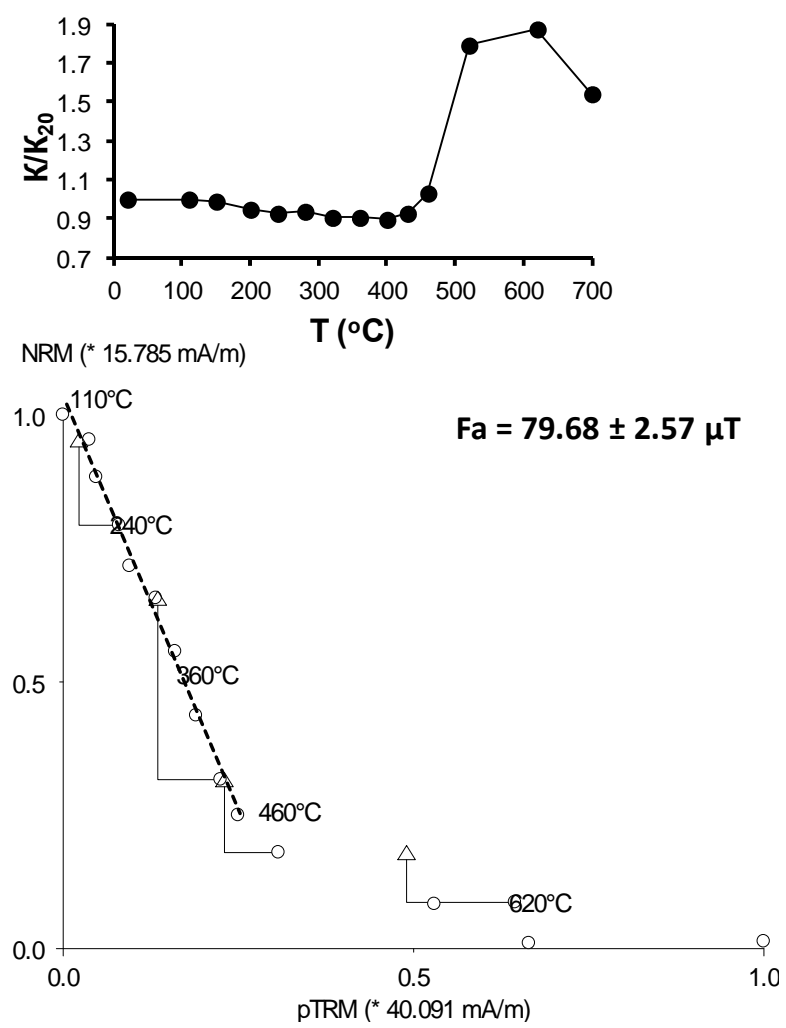

b) Labno 366 (So35d)

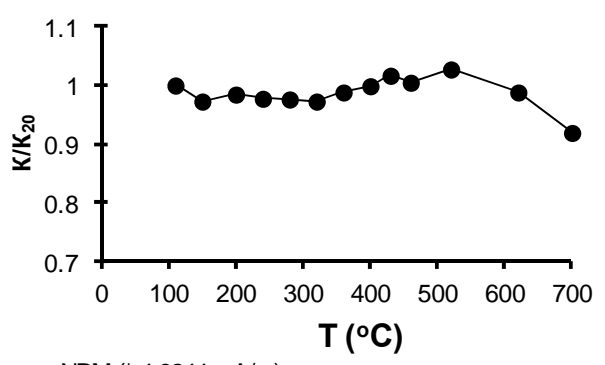

$\mathrm{NRM}\left({ }^{*} 4.9244 \mathrm{~mA} / \mathrm{m}\right)$

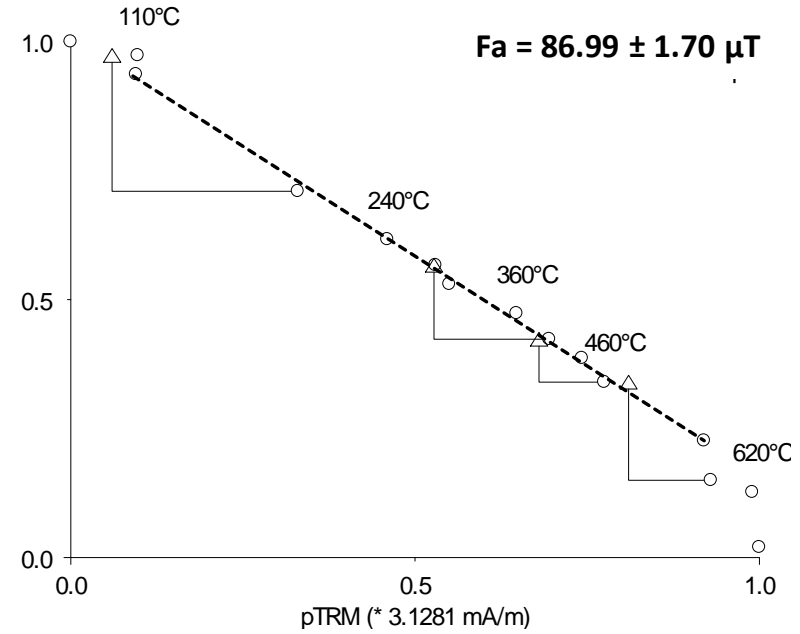

d) Labno 356 (Ma8d)

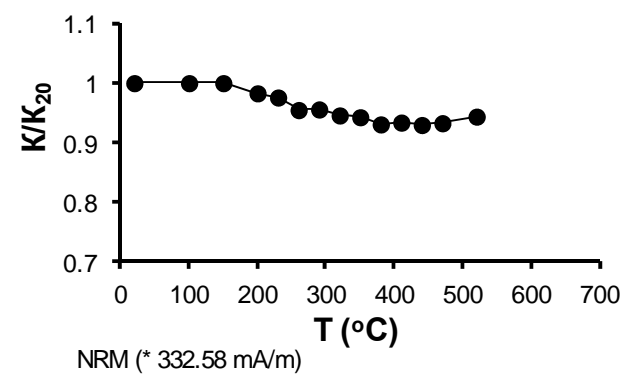

$\mathrm{NRM}\left({ }^{*} 332.58 \mathrm{~mA} / \mathrm{m}\right)$

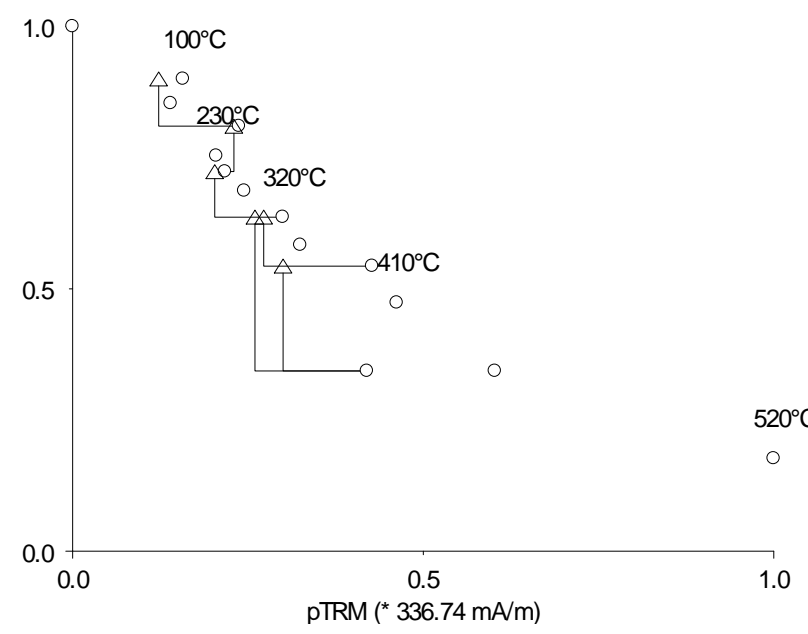


Fig. 6

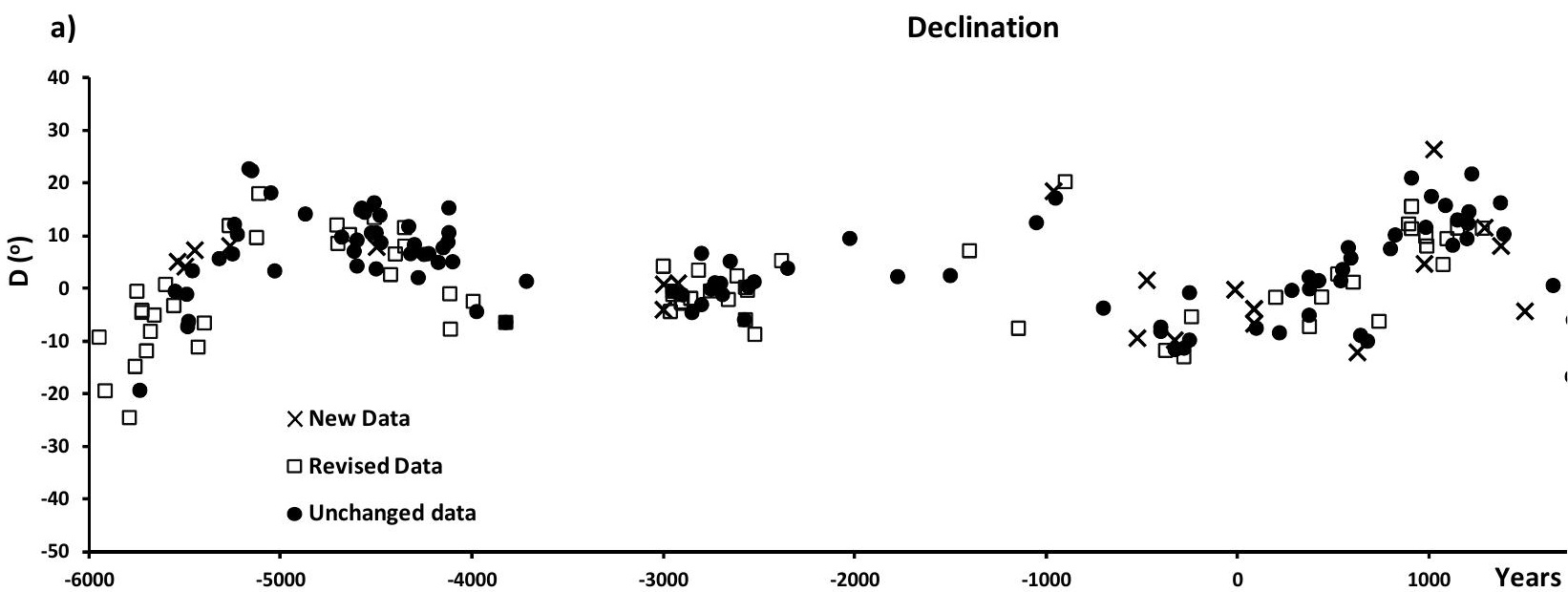

b)

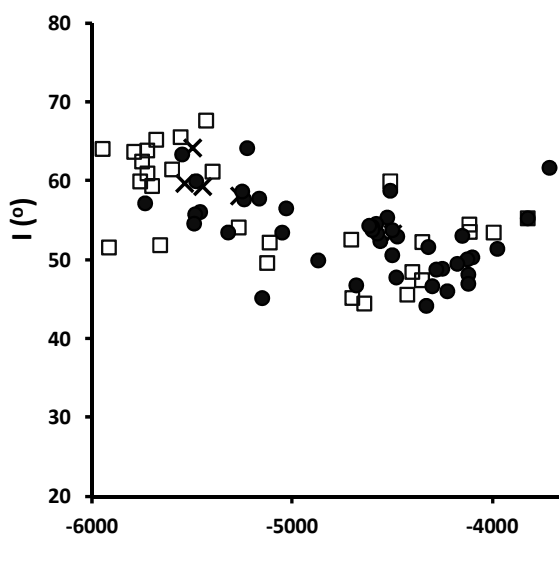

c)

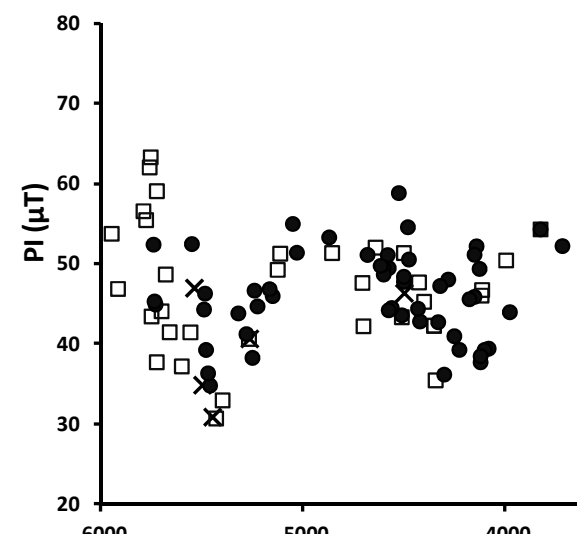

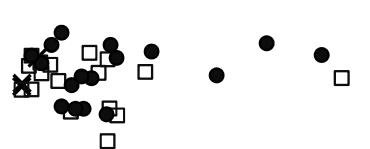

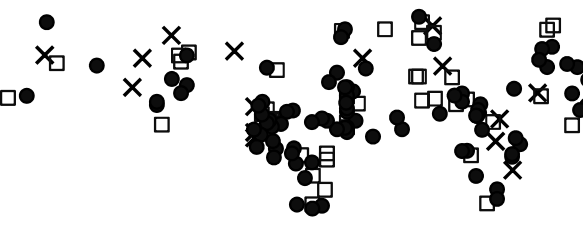

$\times$ New Data

$\square$ Revised Data

- Unchanged data

3000

$-1000$

Palaeointensity

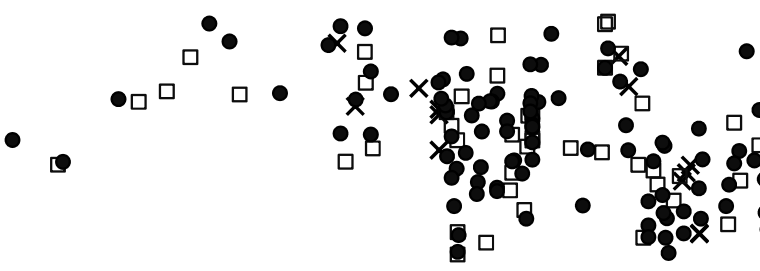

$\times$ New Data

$\square$ Revised Data

- Unchanged data

Fig. 7 

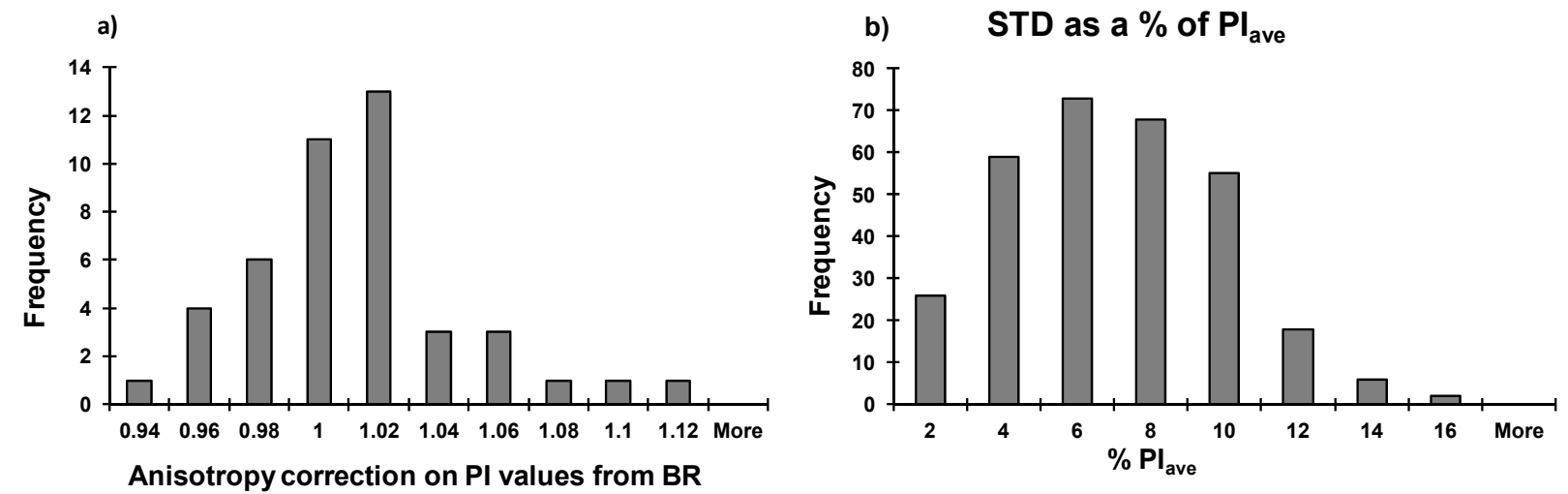

Fig. 8 

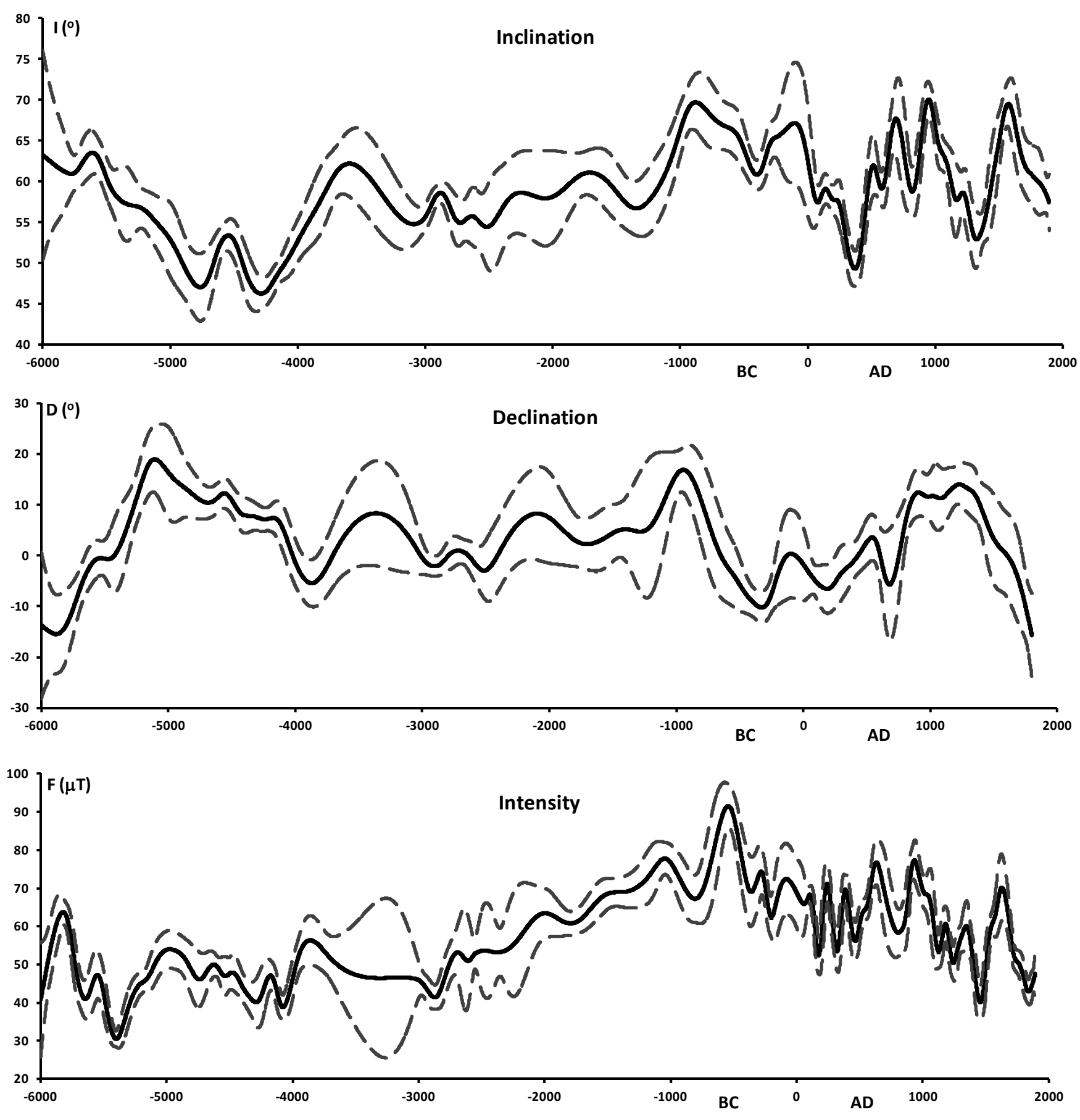

Fig. 9 


\begin{tabular}{|c|c|c|c|c|c|c|c|c|}
\hline LNO & LAT & LONG & PLACE & SITE_HORIZ & MAT & LAGE & HAGE & DTP \\
\hline 239 & 42.20 & 27.80 & Tzarevo & The old church & BR & 1894 & 1894 & 1894 \\
\hline 238 & 43.10 & 25.70 & Veliko_Tarnovo & Preobrajenski monaster & BR & 1893 & 1893 & 1893 \\
\hline 352 & 43.10 & 25.70 & Veliko_Tarnovo & Bricks with incription of the date & BR & 1888 & 1888 & 1888 \\
\hline 237 & 43.10 & 25.70 & Veliko_Tarnovo & Fireplace in a Turkish dwelling & $\mathrm{KL}$ & 1886 & 1886 & 1886 \\
\hline 236 & 43.20 & 27.90 & Varna & Turkish building & BR & 1874 & 1874 & 1874 \\
\hline 235 & 43.10 & 25.70 & Veliko_Tarnovo & Church Saint "Konstantin and Elena" & $\mathrm{BR}$ & 1873 & 1873 & 1873 \\
\hline 234 & 43.10 & 25.70 & Veliko_Tarnovo & Samovodski market & BR & 1868 & 1868 & 1868 \\
\hline 322 & 43.10 & 25.70 & Veliko_Tarnovo & Turkish mosque turned to Christian ch. & $B R$ & 1800 & 1878 & 1839 \\
\hline 226 & 41.50 & 23.40 & Melnik & Fireplace - Kordupulova house & BR & 1800 & 1850 & 1825 \\
\hline 229 & 41.47 & 25.65 & Krumovgrad & Mosque & BR & 1809 & 1809 & 1809 \\
\hline 230 & 41.50 & 25.30 & Djebel & Mosque & $B R$ & 1780 & 1780 & 1780 \\
\hline 227 & 43.00 & 25.50 & Trojan & Furnace for daily ceramics & KL & 1750 & 1800 & 1775 \\
\hline 228 & 43.10 & 25.70 & Veliko_Tarnovo & Tzarevetz-Turkish kiln for daily cer. & $\mathrm{KL}$ & 1750 & 1760 & 1755 \\
\hline 220 & 43.30 & 24.60 & Pleven district & Bivolare-Medieval kiln & $\mathrm{KL}$ & 1700 & 1800 & 1750 \\
\hline 224 & 43.85 & 26.00 & Russe & Bey's house & BR & 1700 & 1730 & 1715 \\
\hline 225 & 42.70 & 23.30 & Sofia & Tombs No3 \& No9 - "St.Spass" & BR & 1690 & 1720 & 1705 \\
\hline 231 & 42.00 & 24.30 & Peshtera & Clock tower & BR & 1701 & 1701 & 1701 \\
\hline 223 & 42.70 & 23.30 & Sofia & Serdica-East door-Turkish dwelling & BR & 1650 & 1700 & 1675 \\
\hline 187 & 41.80 & 24.80 & Assenovgrad & Bachkowski monastir-Dining room & $B R$ & 1650 & 1700 & 1675 \\
\hline 258 & 42.70 & 23.30 & Sofia & Serdica-oven No1 - the Isljam period & $\mathrm{BC}$ & 1550 & 1750 & 1650 \\
\hline 222 & 43.10 & 25.70 & Veliko_Tarnovo & Church "Saint Georges" & $\mathrm{BR}$ & 1612 & 1612 & 1612 \\
\hline 217 & 42.27 & 23.10 & Dupnitza & Mosque & $B R$ & 1540 & 1620 & 1580 \\
\hline 215 & 42.70 & 23.30 & Sofia & The old church - site "St.Spass" & BR & 1550 & 1600 & 1575 \\
\hline 214 & 43.50 & 26.50 & Razgrad & Teke Demir Baba & $B R$ & 1500 & 1600 & 1550 \\
\hline 213 & 42.45 & 26.00 & Grafitovo & Kademli Baba Teke & $B R$ & 1540 & 1560 & 1550 \\
\hline 219 & 43.20 & 27.45 & Provadia & Choban mosque & BR & 1500 & 1600 & 1550 \\
\hline 212 & 41.93 & 25.90 & Harmanli & Kervan saraj & BR & 1500 & 1550 & 1525 \\
\hline 216 & 43.43 & 28.30 & Kavarna & Turkish baths & $B R$ & 1510 & 1530 & 1520 \\
\hline 208 & 42.70 & 23.30 & Sofia & Church "Saint Petka Samardjijska" & BR & 1490 & 1530 & 1510 \\
\hline 364 & 41.80 & 23.50 & Bansko & Sanctuary in Medieval site & BC & 1450 & 1550 & 1500 \\
\hline 209 & 43.10 & 25.70 & Veliko_Tarnovo & Church "Saint Peter and Pavel" & BR & 1330 & 1500 & 1415 \\
\hline 203 & 43.10 & 25.70 & Veliko_Tarnovo & Tzarevetz - the fire - Turk's invasion & $\mathrm{BC}$ & 1393 & 1393 & 1393 \\
\hline 201 & 41.93 & 25.50 & Haskovo & The old & BR & 1385 & 1385 & 1385 \\
\hline 370 & 42.23 & 27.78 & Kit & Urdoviza Fortress-Med.ceramic furnace & KL & 1347 & 1403 & 1375 \\
\hline 361 & 42.23 & 27.78 & Kiten & Urdoviza Fortress-Med.ceramic furnace & $\mathrm{BC}$ & 1347 & 1403 & 1375 \\
\hline 207 & 43.10 & 25.70 & Veliko_Tarnovo & Church "40 Saint Martyrs" & BR & 1350 & 1400 & 1375 \\
\hline 198 & 42.30 & 26.00 & Dyadovo & Medieval layer on top of Bronze Age tell & $\mathrm{BC}$ & 1350 & 1400 & 1375 \\
\hline 363 & 41.50 & 25.30 & Momchilgrad & Sedlare-Pit in Medieval necropolis & $\mathrm{BC}$ & 1280 & 1380 & 1330 \\
\hline 349 & 44.10 & 27.28 & Silistra & Drustur-Medieval furnace No4 & BC & 1270 & 1350 & 1310 \\
\hline & 43.20 & 27.90 & Varna & Medieval church & BR & 1280 & 1320 & 1300 \\
\hline
\end{tabular}

SC DMNDIR DEC INC $\alpha_{95} \quad \mathrm{~K} \quad$ NOPI NPI $\quad$ PI $\quad$ o $\quad$ AN_cor TYPE

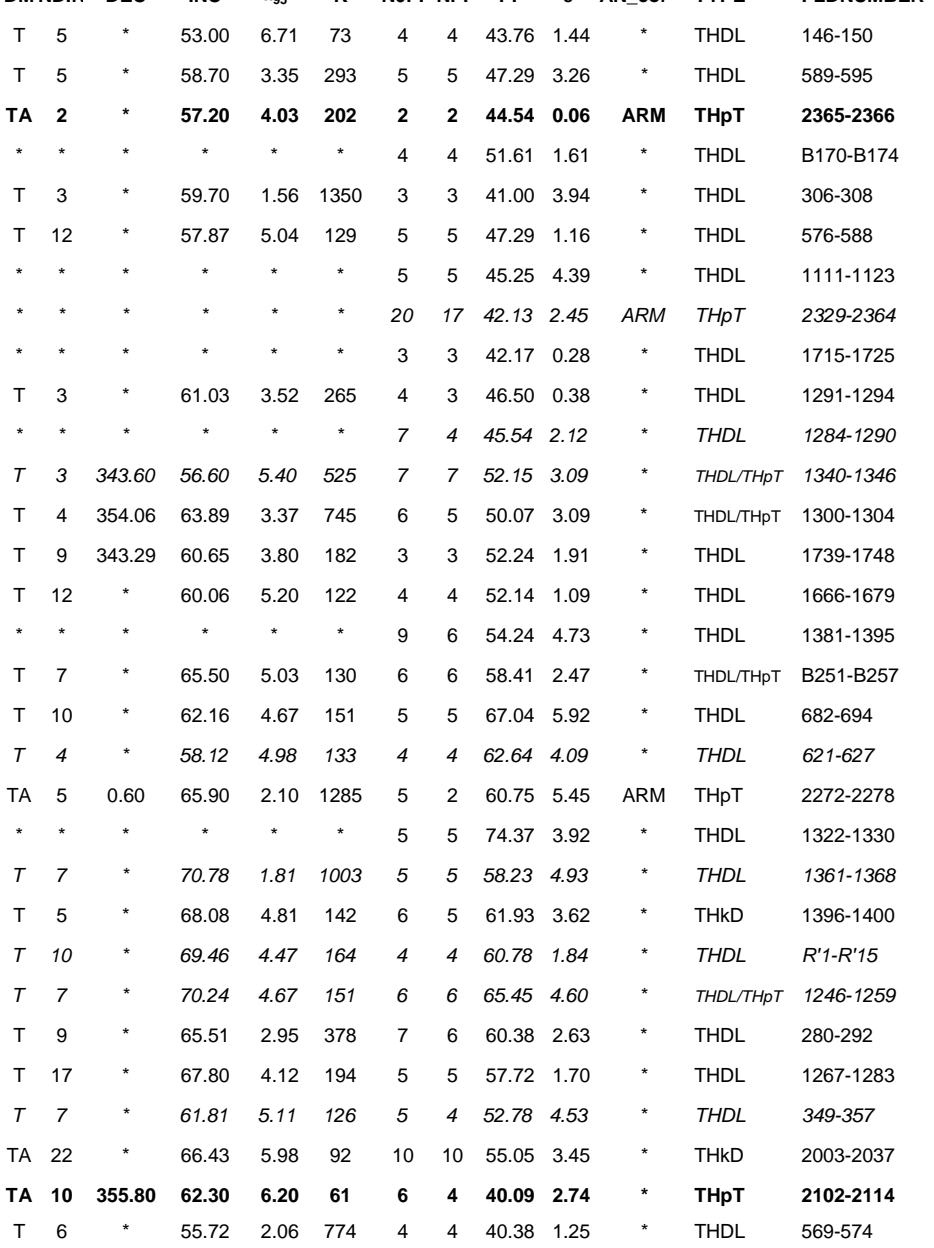

$\begin{array}{lllllllllllll}\text { T } & 8 & 10.36 & 56.49 & 3.70 & 217 & 11 & 9 & 60.88 & 5.76 & * & \text { THDL } & 141-3 / 1688-173 / 1 / 1460-7 / 1 / 1582\end{array}$

$\begin{array}{lllllllllllll}\text { T } & 5 & * & 62.76 & 2.28 & 632 & 6 & 4 & 53.48 & 1.46 & * & \text { THрT } & 57-61\end{array}$

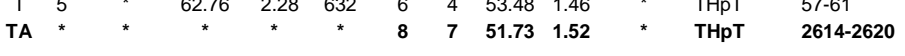

$\begin{array}{lllllllllllll}\text { TA } & 10 & 8.20 & 52.50 & 1.70 & 789 & 17 & 15 & 51.64 & 1.70 & * & \text { THрT } & 2525-2546\end{array}$

$\begin{array}{lllllllllllll}\text { T } & 9 & * & 54.13 & 4.23 & 184 & 5 & 5 & 57.27 & 2.02 & * & \text { THDL } & 1331-1339\end{array}$

$\begin{array}{lllllllllllll}\text { TA } & 10 & 16.30 & 54.47 & 1.80 & 715 & 4 & 4 & 64.72 & 3.71 & * & \text { THDL } & 1750-1762\end{array}$

* * * * * * $\quad 8 \quad 7 \quad 60.223 .96$ * THрT $1943-1958$

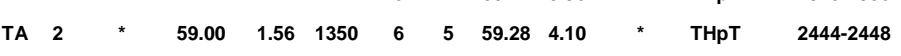

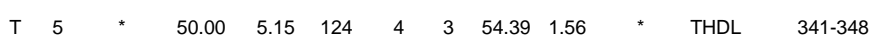

$\begin{array}{lc}\text { DATING } & \text { REF } \\ \text { documents } & 197 \\ \text { documents } & 197 \\ \text { inscription } & \mathbf{2 3 9 , 5 1 9} \\ \text { historical } & 197 \\ \text { documents } & 197 \\ \text { inscription } & 197 \\ \text { inscription } & 502 \\ \text { supposed archaeol.date } & 239,519 \\ \text { historical } & 197 \\ \text { inscription } & 197 \\ \text { documents } & 239,502 \\ \text { archaeological } & 239,502 \\ \text { archaeological } & 502 \\ \text { archaeological } & 502 \\ \text { historical } & 197 \\ \text { archaeological } & 197 \\ \text { historical } & 197 \\ \text { historical } & 197 \\ \text { archaeological } & 239,502 \\ \text { archaeol-.ceramic's feature } & 175 \\ \text { documents } & 502 \\ \text { archaeological } & 239,502 \\ \text { archaeological } & 502 \\ \text { historical (chronicle) } & 239,502 \\ \text { archaeological } & 239,502 \\ \text { archaeological } & 502 \\ \text { historical } & 197 \\ \text { archaeological } & \mathbf{2 3 9} \\ \text { archaeological } & 502 \\ \text { archaeological } & \mathbf{2 3 9} \\ \text { documents } & \mathbf{2 3 9} \\ \text { historical documents } & \mathbf{2 3 9} \\ \text { documents } & 197 \\ \text { coins } & 502 \\ \text { coins } & 502 \\ \text { documents } & \mathbf{2 3 9} \\ \text { archaeological } & \mathbf{2 3 9} \\ \text { archaeological } & 197 \\ \text { archaeological } & \\ \text { archaeological } & \end{array}$




\begin{tabular}{|c|c|c|c|c|c|c|c|c|c|c|c|c|c|c|c|c|c|c|c|c|c|c|}
\hline 185 & 41.50 & 23.40 Melnik & Boyar house & $\mathrm{BR}$ & 1280 & 1320 & 1300 & $\mathrm{~T}$ & 9 & * & 48.79 & 4.68 & 150 & 8 & 7 & 51.64 & 4.97 & * & THDL & 1680-1697 & archaeological & 502 \\
\hline 344 & 44.10 & 27.28 Silistra & Drustur-Medieval furnace №3 & $\mathrm{BC}$ & 1260 & 1320 & 1290 & TA & 10 & 11.67 & 56.16 & 3.05 & 252 & 11 & 9 & 58.24 & 2.81 & * & тНрт & 2422-2437 & coin;stratigraphy & 239 \\
\hline 159 & 44.10 & 27.28 Silistra & Drustur-Medieval furnace & $B C$ & 1250 & 1310 & 1280 & $T A$ & 8 & 11.47 & 58.54 & 4.96 & 126 & 17 & 15 & 58.80 & 2.50 & ARM & THPT & $2380-2403$ & archaeological & 239,502 \\
\hline 204 & 43.80 & 25.60 Cherven & Medieval fortress & $B R$ & 1200 & 1300 & 1250 & $T$ & 10 & * & 48.21 & 5.32 & 116 & 5 & 5 & 55.74 & 4.04 & * & THDL & $1049-1066$ & archaeological & 239,502 \\
\hline 319 & 43.10 & 25.70 Veliko_Tarnovo & Medieval kiln for metal production & $\mathrm{BC}$ & 1200 & 1250 & 1225 & TA & 6 & 21.79 & 57.55 & 3.73 & 324 & 8 & 7 & 49.20 & 1.12 & * & ТНрт & $2318-2328$ & archaeological & 370 \\
\hline 199 & 43.10 & 25.70 Veliko_Tarnovo & King Ivan Assen tomb-"St.40 Martyrs" ch. & $\mathrm{BR}$ & 1203 & 1230 & 1217 & T & 9 & * & 60.79 & 3.48 & 271 & 4 & 4 & 53.53 & 4.75 & * & THDL & $558-568$ & documents, coins & 502 \\
\hline 312 & 41.80 & 26.10 Lubimetz & Orta Burun-sq.E9-10+kiln No1+oven-C7 & KL & 1180 & 1240 & 1210 & TA & 23 & 14.60 & 59.71 & 2.00 & 224 & 15 & 13 & 51.10 & $4.10 \mathrm{~T}$ & TRM;IRM & ТНрт/ТНрТ & 2173-2206 & coins-end12-begin. $13 c . A D$ & 502 \\
\hline 196 & 42.20 & 24.20 Kovachevo & Destructions after an ancient fire & $\mathrm{BC}$ & 1180 & 1230 & 1205 & T & 4 & 12.39 & 60.07 & 6.32 & 212 & 11 & 6 & 62.57 & 2.66 & * & THDL & 1203-1228 & coins & 502 \\
\hline 248 & 43.10 & 25.70 Veliko_Tarnovo & Med. kilns:metal\&domestic production & $\mathrm{BC}$ & 1150 & 1250 & 1200 & TA & 6 & 9.50 & 59.30 & 3.30 & 546 & 7 & 6 & 54.19 & 3.37 & * & THрT & $2438-2443$ & archaeological (ceramic) & 370 \\
\hline 194 & 41.50 & 23.40 Melnik & Despot Slav fortress - Saint Nikola place & $\mathrm{BR}$ & 1180 & 1210 & 1195 & T & 24 & * & 51.70 & 5.40 & 113 & 7 & 4 & 62.97 & 4.87 & * & THDL & 1560-1573//1698-1699 & archaeological & 502 \\
\hline 144 & 42.00 & 24.80 Assenovgrad & Medieval church "Saint Jana" & BR & 1180 & 1210 & 1195 & T & 4 & * & 59.35 & 5.12 & 125 & 6 & 2 & 56.43 & 3.41 & * & ТНрТ & $628-631$ & archaeological & 502 \\
\hline 195 & 42.20 & 24.30 Pazardjik & Tzepina fortress-water reservoirs & $B R$ & 1120 & 1220 & 1170 & $T$ & 22 & * & 54.32 & 5.17 & 123 & 7 & 6 & 57.75 & 5.33 & * & THDL & $971-998 / / 50 / / 51$ & archaeological & 239,502 \\
\hline 188 & 42.50 & 26.00 Assenovets & Medieval settlement-Markova water mill & KL & 1100 & 1200 & 1150 & T & 7 & 13.04 & 54.89 & 3.90 & 238 & 5 & 5 & 60.64 & 3.90 & * & THDL & 1587-1595 & archaeological & 197 \\
\hline 311 & 41.80 & 26.10 Ljubimetz & Orta burun-kiln No2 & KL & 1100 & 1200 & 1150 & $T A$ & 6 & 11.50 & 61.40 & 6.60 & 104 & 5 & 3 & 59.49 & 2.81 & TRM & THPT & $2157-2172$ & coins & 239,502 \\
\hline 192 & 42.00 & 24.80 Assenovgrad & The fortress-church "St.Bogor.Petrichka" & $\mathrm{BR}$ & 1100 & 1150 & 1125 & $\mathrm{~T}$ & 5 & * & 62.16 & 2.01 & 813 & 3 & 3 & 52.64 & 5.63 & * & THDL & 614-619 & historical & 197 \\
\hline 191 & 43.12 & 25.70 Veliko_Tarnovo & Church "Saint Dimitar" & BR & 1100 & 1150 & 1125 & T & 16 & * & 54.86 & 5.24 & 120 & 7 & 7 & 55.64 & 3.06 & * & THDL & $1305-1320$ & historical & 197 \\
\hline 313 & 42.10 & 26.10 Iskritza & Kiln used to the middle of 12 century & $\mathrm{KL}$ & 1100 & 1150 & 1125 & T & 6 & 8.25 & 61.11 & 6.66 & 104 & 5 & 5 & 51.19 & $2.20 \mathrm{~T}$ & TRM;IRM & THрТ & 2208-2216 & archaeological & 197 \\
\hline 271 & 42.10 & 24.20 Patalenitza & The church & $B R$ & 1050 & 1150 & 1100 & * & * & * & * & * & * & 6 & 6 & 51.10 & 4.70 & * & THDL & 1726-1738 & archaeological & 239,502 \\
\hline 197 & 42.60 & 23.00 Pernik & Krakra fortress-burnt soil of ancient fire & $B C$ & 1080 & 1110 & 1095 & $T$ & 7 & 9.50 & 60.80 & 3.70 & 264 & 11 & 5 & 67.86 & 2.92 & * & THDLTHPT & $1347-1360$ & archaeological & 239,502 \\
\hline 210 & 42.10 & 25.43 Chirpan & Zlatna livada-Medieval domestic oven & $\mathrm{BC}$ & 1025 & 1150 & 1088 & TA & 10 & 15.80 & 61.90 & 1.10 & 1832 & 9 & 5 & 72.13 & 3.49 & * & THрт & $2367-2379$ & archaeological & 369 \\
\hline 183 & 43.20 & 26.60 Veliki_Preslav & Patlejna ceramic center & KL & 1050 & 1100 & 1075 & $T$ & 3 & 4.60 & 64.20 & 2.00 & 3916 & 3 & 1 & 60.20 & 2.21 & * & THDL & $892-894 / / 896$ & archaeological & 239,502 \\
\hline 369 & 43.37 & 27.12 Pliska & Palace complex-kiln 2,sq.XX-321 & KL & 1000 & 1050 & 1025 & TA & 3 & 26.50 & 65.70 & 2.70 & 2156 & 6 & 6 & 70.03 & 1.33 & * & тНрт & 2574;2576;2595;2598;2599 & archaeological & 552 \\
\hline 255 & 41.80 & 24.80 Assenovgrad & Bachkovski_monastir-Ossuary & $\mathrm{BR}$ & 1000 & 1050 & 1025 & * & * & * & * & * & * & 1 & 1 & 62.02 & 1.94 & * & THkD & 620 & archaeological & 197 \\
\hline 186 & 41.42 & 23.20 Petrich & The remains of an ancient fire & BS & 1014 & 1014 & 1014 & T & 5 & 17.51 & 59.59 & 5.48 & 196 & 5 & 5 & 65.14 & 3.82 & * & THDL & 1543-1559 & historical & 502 \\
\hline 184 & 43.37 & 27.10 Pliska & The king's estate-prefurnium; furnace & KL & 950 & 1030 & 990 & $T$ & 7 & 8.10 & 61.50 & 5.20 & 137 & 9 & 6 & 74.08 & 5.09 & * & THDL & 634-6391628-1645 & archaeological & 239,502 \\
\hline 180 & 43.40 & 28.20 Balchik & Protobulgarian dwellings & $H R$ & 950 & 1020 & 985 & $T$ & 4 & 9.92 & 69.86 & 3.60 & 628 & 2 & 1 & 80.11 & 8.00 & * & $T H D L$ & $1771-1784$ & archaeological & 239,502 \\
\hline 182 & 43.70 & 28.50 Durankulak & The field - kiln's floor plasters & $\mathrm{KL}$ & 970 & 1000 & 985 & T & 17 & 11.64 & 68.43 & 2.00 & 317 & 11 & 7 & 70.59 & $3.58 \mathrm{~T}$ & TRM;IRM & THКD/THрT & 1763-1766//1785-1802 & archaeological & 502 \\
\hline 368 & 43.37 & 27.12 Pliska & Palace complex-kiln 1,sq.XX-363 & KL & 950 & 1000 & 975 & TA & 12 & 4.80 & 70.80 & 2.30 & 358 & 6 & 6 & 73.80 & 3.04 & * & THрт & 2573; 2575;2577-2592 & archaeological & 552 \\
\hline 178 & 43.20 & 26.82 Veliki_Preslav & The inner fortress wall & $B R$ & 900 & 950 & 925 & $T$ & 4 & * & 61.25 & 4.50 & 162 & 4 & 4 & 78.06 & 7.54 & * & THDL & $742-748$ & archaeological & 239,502 \\
\hline 175 & 44.10 & 26.80 Garvan & Slav settlement & $\mathrm{HR}$ & 900 & 950 & 925 & * & * & * & * & * & * & 7 & 2 & 74.73 & 9.22 & * & THDL & $108-113$ & archaeological & 502 \\
\hline 174 & 43.20 & 26.82 VelikiPreslav & The monastery estate in the inner town & $B R$ & 900 & 950 & 925 & $T$ & 7 & * & 71.21 & 2.53 & 513 & 10 & 9 & 84.03 & 9.24 & * & THDL $T H P T$ & $896-910$ & archaeological & 239,502 \\
\hline 173 & 43.20 & 26.80 Vinitza & Ceramic center of the king's estate & KL & 900 & 920 & 910 & $T$ & 6 & 15.60 & 69.20 & 3.50 & 376 & 7 & 7 & 77.75 & $2.48 \mathrm{~T}$ & TRM;IRM & THDLTHPT & 98-107 & historical & 239,502 \\
\hline 177 & 43.20 & 26.82 Veliki_Preslav & Ceramic center on the road to Patlejna & $\mathrm{KL}$ & 900 & 920 & 910 & T & 4 & 21.02 & 71.89 & 6.52 & 200 & 3 & 3 & 72.30 & $3.09 \mathrm{~T}$ & TRM;IRM & THDLTHPT & 93-97 & archaeological & 502 \\
\hline 176 & 43.20 & 27.90 Varna & Early Bulgarian dwelling & $H R$ & 880 & 940 & 910 & $T$ & 13 & 11.40 & 64.30 & 3.80 & 117 & 8 & 5 & 72.32 & 4.05 & * & THDL & 1435-1459 & historical & 239,502 \\
\hline 179 & 43.70 & 28.60 Durankulak & The island-Medieval horizon-kiln's floor & KL & 870 & 920 & 895 & $T$ & 8 & 12.30 & 64.30 & 7.00 & 64 & 5 & 4 & 61.76 & 0.42 & * & THPT & B521-B531 & archaeological & 239,502 \\
\hline 181 & 43.20 & 27.60 Kipra & Slavonic ceramic center & $\mathrm{KL}$ & 800 & 850 & 825 & TA & 13 & 10.19 & 57.62 & 2.39 & 301 & 10 & 9 & 62.12 & 5.62 & * & THDL & 1803-1818 & archaeological & 502 \\
\hline 343 & 41.70 & 26.30 Kap. Andreevo & Early Medieval settlement & $\mathrm{KL}$ & 780 & 820 & 800 & TA & 57 & 7.57 & 59.11 & 1.75 & 117 & 21 & 9 & 55.12 & 6.62 & * & THрT & $2449-2524$ & coins Yustinian VI & 502 \\
\hline 314 & 43.40 & 28.30 Topola & Kilns under the roof of iron construction & KL & 680 & 800 & 740 & $T A$ & 6 & 353.80 & 70.30 & 4.80 & 196 & 6 & 6 & 62.29 & $3.53 \mathrm{~T}$ & TRM;IRM & THPT & $2217-2226$ & archaeological & 239,502 \\
\hline 170 & 43.50 & 23.20 Montana & Rego Montanensium-kiln floor\&burnt soil & $\mathrm{KL}$ & 600 & 760 & 680 & TA & 5 & 350.03 & 56.69 & 4.12 & 346 & 4 & 3 & 68.52 & 3.95 & * & THDL & $1506-1516$ & archaeological & 197 \\
\hline 172 & 43.10 & 25.70 Veliko_Tarnovo & Tzarevetz - burnt soils after the fire & BS & 641 & 647 & 644 & T & 31 & 351.14 & 65.33 & 2.10 & 143 & 15 & 15 & 76.55 & $5.56 \mathrm{~T}$ & TRM;IRM & THDL/THPT & $135-139 / / 640-666 / / 1574-1581$ & coins\&inscription & 502 \\
\hline 367 & 42.60 & 27.70 Nessebar & Early Byzantine furnace-the floor & KL & 575 & 675 & 625 & TA & 4 & 348.00 & 66.70 & 2.50 & 1406 & * & * & * & * & * & * & 2547;2552;2557;2559 & archaeological & 239 \\
\hline
\end{tabular}




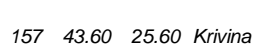
$\begin{array}{lll}296 & 42.70 \quad 23.30 \text { Sofia }\end{array}$ $\begin{array}{lll}167 \quad 43.30 & 27.60 & \text { Sherba }\end{array}$ $\begin{array}{lll}149 & 43.20 & 27.90 \\ \text { Varna }\end{array}$ Jatrus-sqs X-T9; X-B; IX-O-Avar's invasion $\quad B C \quad 590 \quad 620 \quad 605$ Serdica-pottery oven No2 of L.Roman Age $\quad$ BC $\quad \begin{array}{llll}571 & 615 & 593\end{array}$ $\begin{array}{lllll}\text { Remains of a Late Roman kiln } & \mathrm{KL} & 560 & 600 & 580\end{array}$ $\begin{array}{lllll}\text { The Basilica at Djanavar tepe } & \text { BR } & 500 & 600 & 550\end{array}$ $\begin{array}{lll}166 & 42.70 \quad 27.70 \text { Nessebar }\end{array}$ Roman town's wall

17142.9025 .40 Drjanovski_mon. Late Roman tower in Borunja district $\begin{array}{lll}161 & 42.40 \quad 25.70 \text { Hrishtene }\end{array}$ $\begin{array}{lll}163 & 42.68 & 26.33 \text { Novo_selo }\end{array}$ $165 \quad 42.76 \quad 23.30$ Bojana $\begin{array}{lll}155 & 43.40 \quad 28.40 \text { Kaliakra }\end{array}$ $\begin{array}{lll}168 & 43.20 & 27.70 \text { Beloslav }\end{array}$ $\begin{array}{lll}160 & 43.20 & 27.45 \text { Provadija }\end{array}$ $\begin{array}{lll}150 & 42.70 \quad 23.30 \text { Sofia }\end{array}$ $16243.20 \quad 23.90$ Gol. Belene $\begin{array}{lll}256 & 44.00 \quad 22.50 \text { Perilovetz }\end{array}$ $244 \quad 42.30 \quad 22.65$ Kustendil $202 \quad 42.50 \quad 24.30$ Strelcha $156 \quad 43.50 \quad 27.10$ Vojvoda $\begin{array}{llll}143 & 43.70 \quad 24.90 & \text { Nikopo }\end{array}$ $233 \quad 43.10 \quad 24.70$ Lovech $151 \quad 43.70 \quad 22.70$ Macresh $\begin{array}{llll}66 & 43.30 & 27.80 & \text { Varna_district }\end{array}$ $\begin{array}{lll}158 & 43.20 & 27.80 \\ 14 \text { Kisheshlika }\end{array}$ $145 \quad 43.50 \quad 26.50$ Razgrad $\begin{array}{llll}164 & 42.70 & 27.70 & \text { Nessebar }\end{array}$ $146 \quad 42.70 \quad 27.70$ Nessebar $142 \quad 42.50 \quad 23.10$ Kralev_dol $\begin{array}{lll}126 & 43.50 \quad 23.20 \text { Kalimanitza }\end{array}$ $\begin{array}{lll}154 & 42.20 & 24.30 \\ & \text { Pazardjik }\end{array}$ $120 \quad 42.20 \quad 24.80$ Plovdiv $\begin{array}{lll}134 & 41.50 \quad 26.10 \text { Ivajlovgrad }\end{array}$ $\begin{array}{llll}128 & 43.20 & 25.30 \\ \text { Hotnitza }\end{array}$

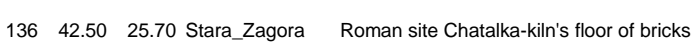
$\begin{array}{lll}121 & 43.10 \quad 25.70 \text { Butovo }\end{array}$ 13541.7025 .70 Dolno_Botevo $\begin{array}{llll}130 & 42.70 & 23.30 \text { Sofia }\end{array}$ $\begin{array}{lll}141 & 42.70 & 23.30 \text { Sofia }\end{array}$ $140 \quad 43.50 \quad 27.10$ Vojvoda $\begin{array}{lll}132 & 42.70 \quad 23.30 \text { Sofia }\end{array}$ $\begin{array}{lll}129 & 42.50 \quad 24.70 \text { Hissarja }\end{array}$ $\begin{array}{lll}123 & 43.60 & 25.35 \\ \text { Svishtov }\end{array}$

\section{Early Christian Basilica}

Well preserved furnace for bricks baking Late Roman Buildings

Re-used L.Roman mat.in Medieval ch.

Material from Dobreva chuka district Re-used bricks in Ovechgrad fortres Serdica-South triangular tower;East door Late Roman basilica

Late Roman fortress Bovonia

Early Medieval sanctuary in Goranovtz Re-used Roman bricks in Med. Fortress Roman Estate-burnt wall made by bricks Christian church in a Roman domination Med. church-re-used Late Roman bricks Roman Basilica-unique abse

Early Byzantine fortress "Muhalijsko tepe" Late antique fortress and settlement Roman town Abritus-fortress's East wall Western wall of the Roman town

\section{Roman public house}

Roman villa

Roman cer.center-Rego Montanensium Tzepina fortress-E.Bizantine ch.+dwell. Philipopol-a road after an ancient fire Roman villa Armira - the fire, hypocaust Roman ceramic center

\section{Roman furnaces}

Roman reservoir

Serdica-E.Christian chuch "St. Georgue" Serdica-East door-tower 2; West. column Late Roman fortress an estate-farm buildings of Serdica Diokletianopol-town gate and wall Roman town Nove - furnaces
BR $\quad 540 \quad 560 \quad 550$

$\begin{array}{llll}B R & 500 & 600 & 550\end{array}$

$\begin{array}{llll}\text { BR } & 500 & 600 & 550\end{array}$

KL $\quad 500 \quad 600 \quad 550$

$\begin{array}{llll}B R \quad 520 & 580 & 550\end{array}$

$\begin{array}{llll}\text { BR } \quad 500 \quad 600 & 550\end{array}$

BR $500 \quad 600 \quad 550$

BR $\quad 500 \quad 600 \quad 550$

BR $\quad 527 \quad 565 \quad 546$

$\begin{array}{llll}\text { BR } \quad 480 & 600 & 540\end{array}$

BR $\quad 520 \quad 560 \quad 540$

$\begin{array}{llll}\mathrm{KL} & 500 & 580 & 540\end{array}$

$B R \quad 500 \quad 560 \quad 530$

bBR $500 \quad 550 \quad 525$

$\begin{array}{llll}\text { BR } \quad 440 \quad 600 & 520\end{array}$

$B R \quad 400 \quad 620 \quad 510$

$\begin{array}{llll}\text { BR } & 450 & 550 & 500\end{array}$

$\begin{array}{llll}\text { BR } \quad 450 \quad 550 & 500\end{array}$

$\begin{array}{llll}\text { BR } \quad 400 & 520 & 460\end{array}$

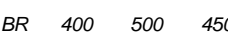

$B R \quad 400 \quad 500 \quad 450$

BR $\quad 400 \quad 500 \quad 450$

KL $400 \quad 480 \quad 440$

T $400 \quad 450 \quad 425$

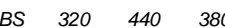

$\begin{array}{lllll}K L & 376 & 378 & 377\end{array}$

$\begin{array}{llll}\text { KL } & 376 & 378 & 377\end{array}$

$\begin{array}{llll}\text { bBR } & 350 & 400 & 375\end{array}$

$\begin{array}{llll}\text { KL } & 370 & 380 & 375\end{array}$

$\begin{array}{llll}\text { BR } & 300 & 400 & 350\end{array}$

$\begin{array}{llll}\text { BR } & 300 & 380 & 340\end{array}$

$\begin{array}{llll}B R & 310 & 360 & 335\end{array}$

$\begin{array}{llll}B R & 306 & 337 & 322\end{array}$

$\begin{array}{llll}\text { BR } & 250 & 350 & 300\end{array}$

$\begin{array}{llll}\text { BR } & 280 & 310 & 295\end{array}$

$\begin{array}{llll}\text { KL } \quad 270 & 300 & 285\end{array}$
$\begin{array}{lllllllllllll}T & 16 & 1.24 & 60.87 & 3.30 & 123 & 11 & 11 & 83.21 & 7.86 & * & \text { THDL } & 827-831 / 854-874\end{array}$

$\begin{array}{lllllllllllll}\text { TA } & 18 & 5.80 & 58.70 & 1.90 & 324 & 11 & 8 & 72.68 & 2.90 & \text { ARM } & \text { THрT } & 2279-2304\end{array}$

$\begin{array}{llllllllllll}\text { T } & 5 & 7.80 & 62.42 & 4.23 & 328 & 4 & 4 & 68.04 & 3.90 & \text { TRM;/RM THрT } & 83-87\end{array}$

$\begin{array}{lllllllllllll}\text { T } & 4 & * & 57.88 & 2.66 & 464 & 6 & 5 & 65.99 & 5.58 & \text { TRM;IRM THDLTHPT } & 302-305\end{array}$

KL $\quad 380 \quad 470 \quad 425$
$\begin{array}{llllllllllll}T & 5 & * & 62.96 & 5.22 & 121 & 7 & 5 & 60.84 & 4.00 & \text { TRM;IRM THDL } / \text { THPT } & 376-381\end{array}$

$\begin{array}{llllllllllllll}T & 11 & * & 57.87 & 3.40 & 284 & 6 & 4 & 66.45 & 6.97 & * & \text { THDLTHPT } & 1124-1138\end{array}$

$\begin{array}{lllllllllll}\text { T } 11 & * & 57.27 & 4.21 & 185 & 6 & 6 & 65.22 & 6.58 & \text { TRM;IRM THDLTHPT } & \text { B207-B218 }\end{array}$

$\begin{array}{llllllllllll}\text { T } & 7 & 3.63 & 59.84 & 3.90 & 234 & 5 & 5 & 63.01 & 4.75 & \text { TRM;IRM THDL } T H P T & 548-557\end{array}$

$\begin{array}{llllllllllllll}T & 9 & * & 58.49 & 2.70 & 451 & 9 & 9 & 63.56 & 5.01 & * & \text { THDL } & 962-970\end{array}$

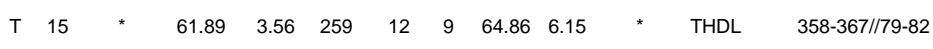

$\begin{array}{lllllllllllll}T & 5 & * & 61.76 & 4.38 & 171 & 3 & 3 & 63.23 & 3.46 & * & T H k D & 240-246\end{array}$

T 5 * * $\quad \begin{array}{lllllllllll} & 60.28 & 6.74 & 72 & 4 & 3 & 64.96 & 2.91 & * & \text { THDL } & 293-301\end{array}$

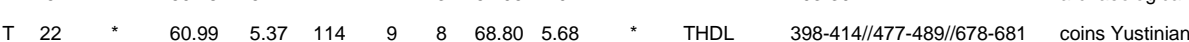

$\begin{array}{llllllllllllll}T & 14 & * & 62.94 & 3.27 & 307 & 6 & 6 & 72.74 & 1.60 & * & \text { THKD/THPT } & 1230-1245 & \text { archaeological }\end{array}$

$\begin{array}{llllllllllllllll}\mathrm{T} & 2 & * & 70.30 & 1.41 & 1653 & 3 & 3 & 67.89 & 3.15 & * & \mathrm{THKD} & 777-778 & & & \end{array}$

$\begin{array}{lllllllllllllll}\text { T } & 10 & 1.50 & 57.80 & 3.50 & 188 & 6 & 6 & 66.86 & 4.87 & * & \text { THDL } & 1933-1942 & \text { archaeological }\end{array}$

* * * * * * 7666.334 .71 * THDLTHPT 1596-1609

$\begin{array}{lllllllllllll}T & 6 & 2.80 & 70.10 & 5.90 & 94 & 5 & 5 & 62.47 & 1.34 & * & \text { THDL } & 911-914 / 928-931\end{array}$

T $\quad 7 \quad * \quad 69.30 \quad 2.91 \quad 388 \quad 3 \quad 3 \quad 53.48 \quad 1.16 \quad * \quad$ THDL $\quad 802-809$

* * * * * * $8 \quad 8 \quad 54.564 .22 \quad * \quad$ THDL $1139-1150$

TA 5 * $\quad \begin{array}{llllllllllll}57.62 & 1.35 & 1803 & 5 & 4 & 59.11 & 2.66 & * & \text { THpT } & 771-776\end{array}$

T 5 * $64.80 \quad 3.34295$ * * * * * * * $313-319$

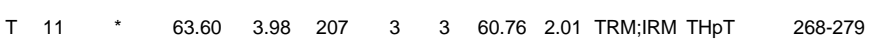

TA 5 * * $\quad \begin{array}{lllllllllll}54.56 & 5.40 & 113 & 2 & 2 & 63.96 & 0.67 & * & \text { THDL } & 1068-1076\end{array}$

$\begin{array}{lllllllllllll}T & 3 & * & 53.77 & 3.50 & 268 & 4 & 4 & 59.21 & 2.57 & \text { TRM:IRM THDLTHPT } & 68-70\end{array}$

$\begin{array}{lllllllllll}T \text { TA } 14 & * & 58.70 & 4.90 & 137 & 7 & 7 & 60.63 & 2.37 & \text { TRM;IRM THDLTHPT } & \text { B175-B182//71-72 }\end{array}$

$\begin{array}{lllllllllllll}\text { TA } & 10 & 358.43 & 49.94 & 2.60 & 326 & 7 & 6 & 57.01 & 5.35 & * & \text { THPT } & 1151-1162\end{array}$

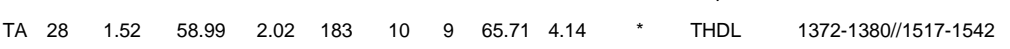

T 10 * $\quad \begin{array}{lllllllllll}47.92 & 3.98 & 207 & 6 & 4 & 64.38 & 4.58 & * & \text { THKD } & 1003-1008 / 1016-1023 / 48 / 49\end{array}$

$\begin{array}{lllllllllllll}T & 4 & * & 51.73 & 2.08 & 760 & 2 & 2 & 76.36 & 5.94 & * & \text { THDL } & \text { B242-B250 }\end{array}$

$\begin{array}{lllllllllllll}T & 5 & 352.82 & 48.09 & 5.40 & 201 & 5 & 5 & 71.33 & 2.40 & * & T H D L & 161-6 / 382-97 / 14401-03 / 1 / 428\end{array}$

$\begin{array}{lllllllllllll}\text { T } & 12 & 359.97 & 47.56 & 4.20 & 103 & 6 & 5 & 69.08 & 5.57 & * & \text { THDL } & 144 / 182-183 / 653-662\end{array}$

$\begin{array}{lllllllllllll}\text { T } & 5 & 354.95 & 53.42 & 6.10 & 88 & 7 & 7 & 57.35 & 2.92 & * & \text { THDL } & 200-211\end{array}$

$\begin{array}{lllllllllllll}\text { T } & 14 & 2.17 & 58.53 & 4.70 & 70 & 15 & 14 & 56.92 & 4.86 & * & \text { THDL } & 126-130 / 176 / / 878-890\end{array}$

* * * * * $7 \begin{array}{llllllll}7 & 7 & 68.11 & 1.03 & * & \text { THDL } & 54-56 / 1260-1266\end{array}$

T 12 * $\quad \begin{array}{llllllllll}51.43 & 5.62 & 104 & 6 & 5 & 68.13 & 6.30 & * & \text { THDL } & 415-423 / 709-714\end{array}$

$\begin{array}{lllllllllllll}T & 11 & * & 49.93 & 6.24 & 84 & 8 & 8 & 53.71 & 4.18 & * & \text { THDL } & 667-677 / / 695-699\end{array}$

$\begin{array}{lllllllllllll}T & 10 & * & 54.33 & 6.90 & 69 & 8 & 8 & 50.49 & 3.68 & * & \text { THDL } & 915-927 / 1646\end{array}$

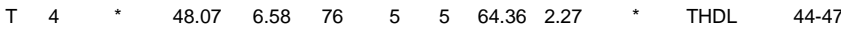

T $\quad 25 * \begin{array}{lllllllllll} & 53.27 & 3.88 & 218 & 26 & 15 & 59.91 & 2.29 & \text { ARM } & \text { THDLTHPT } & 596-611 / 2305-2317\end{array}$

$\begin{array}{lllllllllllll}\text { T } & 9 & 359.67 & 55.20 & 5.20 & 122 & 7 & 7 & 67.84 & 1.55 & * & \text { THDL } & 115-123\end{array}$ archaeological

archaeological

archaeological

archaeological

archaeological

archaeological

archaeological

archaeological

archaeological

rchaeological

archaeological

archaeological

archaeological

archaeological

archaeological

archaeological

archaeological

archaeological

239,502

175

197

502

502

239,502

502
502

239,502

502

239,502

502

197

502

502
239,502

239,502

502

239,502

197

239,502

239,502

502

239,502

502

239,50

239,502

197

502

197

502

239,502

239,502

archaeological

seal Dules

archaeological

archaeological

archaeological 


\begin{tabular}{|c|c|c|c|c|c|c|}
\hline 127 & 43.50 & 26.50 Razgrad & Roman town Abritus & BR & 260 & 300 \\
\hline 125 & 43.10 & 25.70 Butovo & Roman construction\&necropolis & BR & 250 & 300 \\
\hline 131 & 43.70 & 24.50 Gigen & Roman town Escues-a building; a bath & $\mathrm{BR}$ & 200 & 300 \\
\hline 117 & 43.60 & 25.35 Svishtov & Roman town Nove - bricks & BR & 200 & 300 \\
\hline 122 & 43.20 & 26.50 Targoviste & Burnt stones in the ritual ovens & bST & 200 & 250 \\
\hline 112 & 43.20 & 25.30 Pavlikeni & Furnaces-big Roman ceramic center & $\mathrm{KL}$ & 200 & 240 \\
\hline 113 & 42.50 & $26.50 \mathrm{Jambol}$ & Kabile - furnace & KL & 150 & 250 \\
\hline 116 & 42.50 & 25.70 Stara_Zagora & Augusta Trajana-Roman public houses & BR & 170 & 220 \\
\hline 153 & 43.20 & 27.60 Devnja & Marcianopol-E.Chr.Basilica:re-used mat. & BR & 170 & 200 \\
\hline 111 & 43.20 & 25.50 Nikjup & Nikopolis ad Istrum & $B R$ & 170 & 190 \\
\hline 148 & 43.00 & 27.80 Bjala & Erite-Roman road station-re-used mat. & $B R$ & 140 & 220 \\
\hline 115 & 43.20 & 27.60 Devnja & Marcianopol-gladiatorial's fight amphith. & BR & 160 & 200 \\
\hline 110 & 42.70 & 23.30 Sofia & Serdica - the monetary house & $B R$ & 176 & 180 \\
\hline 104 & 43.20 & 27.90 Varna & The Roman thermes & BR & 150 & 200 \\
\hline 109 & 42.50 & 25.70 Stara_Zagora & Augusta Trajana-the mineral baths & $\mathrm{BR}$ & 162 & 163 \\
\hline 124 & 42.50 & 23.10 Kralev_dol & Roman villa & $B R$ & 120 & 200 \\
\hline 106 & 43.60 & 25.60 Krivina & Jatrus-2d c.bricks in $3 d$ c.building-sq. $9 F$ & BR & 100 & 200 \\
\hline 103 & 41.90 & 25.60 Haskovo & The Roman mineral baths & BR & 100 & 200 \\
\hline 108 & 42.30 & 22.65 Kjustendil & Pautalia-the fortress wall and the citadel & $B R$ & 100 & 200 \\
\hline 240 & 42.90 & 23.00 Gaber & Antique building & BR & 50 & 250 \\
\hline 105 & 43.20 & 25.00 Kalvaka & The tomb & BS & 117 & 138 \\
\hline 284 & 43.80 & 22.80 Vartop & Jidkovetz-triangular brick & BR & 117 & 138 \\
\hline 107 & 42.20 & 24.80 Plovdiv & Roman Philipopol - the Forum & $B R$ & 100 & 150 \\
\hline 102 & 43.60 & 27.70 Dobrogled & The East Roman fortress & BR & 100 & 150 \\
\hline 114 & 41.50 & 26.10 Ivajlovgrad & Roman villa Armira & $\mathrm{BR}$ & 100 & 140 \\
\hline 101 & 43.70 & 24.90 Nikopol & The Roman fortress - East part & $B R$ & 98 & 117 \\
\hline 99 & 42.50 & 25.90 Karanovo & Settlement-the furnace and the grave & $\mathrm{BC}$ & 81 & 117 \\
\hline 346 & 43.64 & 25.59 Krivina & Lime workshop of Legio I Italica & $\mathrm{BC}$ & 70 & 100 \\
\hline 347 & 43.64 & 25.59 Krivina & Lime workshop of Legio I Italica & KL & 70 & 100 \\
\hline 348 & 43.64 & 25.59 Krivina & Lime workshop of Legio I Italica & KL & 70 & 100 \\
\hline 98 & 42.70 & 23.30 Sofia & Roman town Serdica-the aquadukt & BR & 50 & 120 \\
\hline 345 & 43.64 & 25.59 Krivina & Roman pottery kiln & BC & -60 & 30 \\
\hline 96 & 42.50 & 27.50 Burgas & Mandrensko ezero - Tursis & $\mathrm{BC}$ & -200 & -100 \\
\hline 253 & 43.72 & 26.71 Isperih & Teke Demir Baba-Thracian sanctuary & $B C$ & -280 & -200 \\
\hline 274 & 43.72 & 26.71 Isperih & Tracian site at Water supply station & $\mathrm{BC}$ & -260 & -240 \\
\hline 56 & 43.70 & 26.75 Isperih & Sborjanovo-hill28+fireplace-hill30(GSM) & $\mathrm{BC}$ & -300 & -200 \\
\hline 279 & 43.10 & 25.70 Veliko_Tarnovo & Thracian oven-the floor & $B C$ & -350 & -200 \\
\hline 100 & 42.24 & 25.22 Halka_Bunar & Pottery center-Thracia (Early Hellenistic) & $B C$ & -280 & -278 \\
\hline 277 & 42.25 & 24.08 Vetren & Pistiros Emporion-hN1,r4+r2;sqB7,B1/B2 & $B C$ & -280 & -279 \\
\hline 93 & 42.50 & 25.40 Kazanlak & Thracian town Seuthopolis-the tomb & $B R$ & -320 & -260 \\
\hline 288 & 42.25 & 24.08 Vetren & Pistiros Emporion-altars-B'2,B'7 & $\mathrm{BC}$ & -350 & -300 \\
\hline
\end{tabular}

\begin{tabular}{|c|c|c|c|c|c|c|c|c|c|c|c|c|}
\hline T & 20 & * & 60.00 & 4.47 & 164 & 5 & 5 & 58.04 & 1.11 & * & THDL & 1077-1097 \\
\hline T & 5 & * & 54.56 & 1.32 & 1886 & 4 & 4 & 56.56 & 2.91 & * & THDL & 124-125//174-175 \\
\hline T & 18 & * & 59.84 & 5.27 & 118 & 7 & 7 & 66.36 & 5.46 & * & THDL & $752-770$ \\
\hline T & 2 & * & 50.20 & 0.28 & 41873 & 4 & 3 & 60.27 & 1.16 & * & THDL & $35-37$ \\
\hline * & * & * & * & * & * & 2 & 2 & 71.55 & 0.96 & * & THDL & 1838-1846 \\
\hline T & 49 & 351.62 & 58.30 & 1.90 & 111 & 23 & 23 & 61.69 & 5.40 & * & THDL & 1099-110//B158-69//1182-94 \\
\hline$T$ & 7 & 358.34 & 65.13 & 4.79 & 143 & 7 & 6 & 68.74 & 3.82 & * & THDL & $B 331-B 343$ \\
\hline T & 29 & * & 55.16 & 5.65 & 103 & 10 & 9 & 75.97 & 5.85 & * & THDL & 184-188//1024-1048 \\
\hline T & 8 & * & 54.05 & 5.88 & 95 & 1 & 1 & 51.43 & 3.00 & * & THDL & $333-340$ \\
\hline$T$ & 11 & * & 58.72 & 4.31 & 177 & 6 & 6 & 51.80 & 3.53 & * & $T H D L$ & $132-134 / / 1468-1478$ \\
\hline$T$ & 8 & * & 58.42 & 1.94 & 873 & 4 & 4 & 49.01 & 4.82 & * & THDL & $257-267$ \\
\hline T & 6 & * & 56.12 & 2.06 & 774 & 5 & 5 & 49.34 & 1.92 & * & THDL & 327-332 \\
\hline$T$ & 17 & * & 58.94 & 4.00 & 205 & 9 & 6 & 63.27 & 3.69 & * & THDL & 1819-1837 \\
\hline T & 4 & * & 57.93 & 3.66 & 245 & 6 & 6 & 59.72 & 2.43 & * & THDL & $73-76$ \\
\hline T & 21 & * & 58.78 & 4.81 & 142 & 5 & 5 & 55.05 & 4.94 & * & THDL & 715-724//B190-B206 \\
\hline$T$ & 13 & * & 58.77 & 4.71 & 148 & 6 & 6 & 80.11 & 4.60 & * & THDL & $1163-1180$ \\
\hline T & 21 & * & 65.43 & 5.45 & 111 & 12 & 11 & 58.58 & 3.51 & * & THDL & $933-852$ \\
\hline * & * & * & * & * & * & 2 & 2 & 63.75 & 2.46 & * & THDL & $52-53$ \\
\hline$T A$ & 18 & * & 60.14 & 4.41 & 169 & 14 & 11 & 65.08 & 3.95 & * & THDLTTHPT & 953-961 \\
\hline T & 15 & * & 58.40 & 4.88 & 138 & 6 & 5 & 76.08 & 4.98 & * & THDL & $725-741$ \\
\hline T & 4 & * & 61.10 & 4.92 & 136 & 3 & 3 & 66.82 & 4.68 & * & THDL & $177-181$ \\
\hline * & * & * & * & * & * & 3 & 3 & 61.27 & 2.66 & * & THDL & 38 \\
\hline$T$ & 9 & * & 59.53 & 4.47 & 164 & 3 & 3 & 66.76 & 4.64 & * & THDL & B225-B241 \\
\hline $\mathrm{T}$ & 8 & * & 59.49 & 5.48 & 109 & 1 & 1 & 66.75 & 1.95 & * & THKD & $247-256$ \\
\hline $\mathrm{T}$ & 24 & * & 56.92 & 5.13 & 125 & 22 & 16 & 67.61 & 3.96 & * & THDL & 388-394//1414-1427 \\
\hline $\mathrm{T}$ & 12 & * & 60.62 & 5.82 & 97 & 4 & 4 & 70.86 & 2.99 & * & THkD & $810-821$ \\
\hline $\mathrm{T}$ & 5 & 352.50 & 55.38 & 6.10 & 159 & 8 & 7 & 68.45 & 0.48 & * & THDL & $1610-1627$ \\
\hline TA & 10 & 353.44 & 60.56 & 2.54 & 364 & 6 & 6 & 66.51 & 2.80 & * & THрт & Lv1-Lv10 \\
\hline TA & 8 & 356.20 & 56.60 & 2.72 & 426 & 9 & 7 & 62.10 & 3.80 & * & ТНрТ & Lv11-Lv23 \\
\hline TA & 23 & 356.26 & 57.29 & 1.93 & 246 & 20 & 18 & 67.20 & 4.50 & * & THрт & Lv35-Lv59 \\
\hline $\mathrm{T}$ & 5 & * & 57.58 & 4.43 & 167 & 2 & 2 & 70.48 & 5.16 & * & THDL & $403-407$ \\
\hline TA & 5 & 359.90 & 67.60 & 5.60 & 191 & 9 & 9 & 69.82 & 3.50 & * & THрт & Lv24-Lv32 \\
\hline * & * & * & * & * & * & 3 & 2 & 69.01 & 0.43 & * & THDL & $1654-1662$ \\
\hline$T$ & 32 & 354.66 & 67.36 & 1.58 & 259 & 28 & 26 & 62.25 & 5.12 & * & THKDTTHPT & 1879-96//1918-26/1988-2002 \\
\hline TA & 21 & 350.23 & 63.22 & 1.84 & 298 & 26 & 23 & 71.85 & 3.91 & TRM:IRM & THрT & $2038-2065 / / 2115-40$ \\
\hline TA & 44 & 359.23 & 66.98 & 0.96 & 499 & 22 & 16 & 63.98 & 2.77 & TRM;IRM & THрТ & DG22-DG58//DG3-DG21 \\
\hline * & * & * & * & * & * & 12 & 12 & 70.44 & 2.95 & * & THPT & VT1-VT8 \\
\hline TA & 12 & 348.70 & 62.20 & 2.70 & 270 & 24 & 20 & 77.23 & 2.17 & * & ТНрТ & HB1-17//HB32-34 \\
\hline$T A$ & 5 & 347.10 & 66.20 & 5.20 & 217 & 18 & 17 & 74.29 & 6.70 & TRM;IRM & THPT & 2066-2094//2247-2255 \\
\hline$T$ & 6 & * & 66.98 & 4.21 & 185 & 9 & 7 & 80.29 & 7.46 & * & $T H D L$ & $272832333439-43$ \\
\hline ГA & 15 & 348.45 & 64.00 & 2.22 & 260 & 6 & 1 & 68.34 & 5.10 & TRM;IRM & ТНрТ & 2228-40//2263-70 \\
\hline
\end{tabular}

archaeologica

archaeologica

archaeological

archaeological

archaeological

archaeological

archaeological

archaeological

archaeological

coins

archaeological

archaeological

coins

coins

inscription

archaeological

archaeological

archaeological

archaeological

archaeological

coins

inscription Hadrien

archaeological

archaeological

archaeological

coins-Domician and Trajan

coins-end of 1 st $C . A D$

coins-end of 1st c.AD

coins-end of 1st c.AD

archaeological

archaelogical;stratigraphy

archaeological

archaeological

coins; inscriptions; seals

archaeological

archaeological

coins Demetrius, Polircete

archaeo;coins;graffit

coins\&archaeological

coins; archaeol.; graffiti;

502

197

197
197

239,502

197

502

239,502

239,502

553

239,502

553
197

239,502

197

197

239,502

197
197

239,502

502

197

197

502

509

509

197

509

197

239,502

502

502

239,502 239,50 
$\begin{array}{lll}357 & 42.65 & 27.72 \\ & \text { Nessebar }\end{array}$

$283 \quad 42.25 \quad 24.08$ Vetren

Elinistic kiln

Pistiros Emporion-baked floor-sq.B

9243.10 24.30 Lazar_Stanevo Mogila 25, Toros 174, oriented sample

$320 \quad 43.1025 .70$ Veliko Tarnovo Two Thracian baked floors

$362 \quad 42.2525 .47$ Malko_Tranovo Remains of Elinistic ovens

$15 \quad 41.6025 .40$ Kardzhali Vishegrad-Iron Age (Thracia)-fired floor

$\begin{array}{lll}366 & 42.42 & 27.70 \\ \text { Sozopol }\end{array}$

$\begin{array}{lll}365 & 42.42 & 27.70 \\ \text { Sozopol }\end{array}$

\section{Metalurgic ovens}

Big pottery oven

$\begin{array}{llll}88 & 42.20 & 24.80 & \text { Plovdiv }\end{array}$

Nebet Tepe-Thracian town Evmolpia

9042.5025 .70 Stara_Zagora Pshenichevo-Iron Age-destructions

$252 \quad 43.74 \quad 26.74$ Isperih

$\begin{array}{lll}356 & 42.55 & 26.78 \text { Malenovo }\end{array}$

$\begin{array}{lll}87 \quad 42.20 & 24.80 \text { Plovdiv }\end{array}$

$82 \quad 43.70 \quad 28.60$ Durankulak

31641.7723 .50 Blagoevgrad

$\begin{array}{lll}80 & 42.20 \quad 24.80 \text { Plovdiv }\end{array}$

$\begin{array}{llll}84 & 41.60 & 25.40 \text { Kardzhali }\end{array}$

$\begin{array}{lll}321 & 42.10 \quad 25.80 \text { Galabovo }\end{array}$

$\begin{array}{llll}85 & 42.20 & 24.80 & \text { Plovdi }\end{array}$

$\begin{array}{lll}77 & 42.20 & 24.80 \\ & \text { Plovdiv }\end{array}$

$\begin{array}{lll}79 & 42.20 & 24.30 \\ 74 & \text { Yunatzite }\end{array}$

$\begin{array}{llll}78 & 42.50 & 26.00 & \text { Nova_Zagora }\end{array}$

$\begin{array}{ll}304 & 42.60 \quad 24.77 \text { Daben }\end{array}$

$\begin{array}{llll}81 & 42.20 & 24.30 & \text { Yunatzite }\end{array}$

$\begin{array}{lll}76 & 42.50 & 26.00 \\ & \text { Nova Zagora }\end{array}$

$\begin{array}{lll}303 & 42.60 & 24.77 \text { Daben }\end{array}$

$\begin{array}{llll}325 & 41.63 & 24.40 \text { Trigrad }\end{array}$

$\begin{array}{llll}278 & 42.30 & 26.00 & \text { Dyadovo }\end{array}$

$\begin{array}{lll}309 & 42.12 \quad 26.08 \text { Galabovo }\end{array}$

$\begin{array}{lll}280 & 42.30 & 26.00 \\ & \text { Dyadovo }\end{array}$

$\begin{array}{lll}71 & 42.20 & 24.30 \\ \text { Yunatzite }\end{array}$

28142.30 26.00 Dyadovo

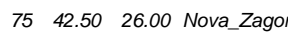

$\begin{array}{lll}64 & 42.20 & 24.30 \\ & \text { Yunatzite }\end{array}$

$\begin{array}{lll}74 & 42.20 & 24.80 \\ \text { Plovdiv }\end{array}$

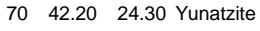

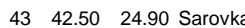

$\begin{array}{lll}289 & 42.30 & 26.00 \\ & \text { Dyadovo }\end{array}$

$\begin{array}{lll}275 & 42.20 & 26.10 \\ & \text { Staroseletz }\end{array}$

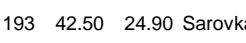

$\begin{array}{lll}286 & 42.50 \quad 26.00 \text { Ezero }\end{array}$
Trench H18-4-2d lev.dwrd+sq.P16
$\begin{array}{llll}B C & -380 & -280 & -330\end{array}$

$\begin{array}{llll}B C & -400 & -350 & -375\end{array}$

$\begin{array}{llll}\text { BS } & -420 & -380 & -400\end{array}$

$\begin{array}{llll}\text { BC } & -500 & -300 & -400\end{array}$

$\begin{array}{llll}B C & -500 & -340 & -420\end{array}$

$\begin{array}{llll}\text { BC } & -560 & -360 & -460\end{array}$

$\begin{array}{llll}\text { BC } & -500 & -450 & -475\end{array}$

$\begin{array}{llll}B C & -550 & -500 & -525\end{array}$

$\begin{array}{llll}B C & -800 & -600 & -700\end{array}$

$\begin{array}{llll}B C & -1000 & -800 & -900\end{array}$

$\begin{array}{llll}H R & -1000 & -900 & -950\end{array}$

$\begin{array}{llll}\text { HR } & \mathbf{- 1 0 1 2} & \mathbf{- 9 1 4} & -963\end{array}$

$\begin{array}{llll}\text { BC } & -1100 & -1000 & -1050\end{array}$

$\begin{array}{lllll}K L & -1302 & -986 & -1144\end{array}$

$\begin{array}{llll}\text { BS } & -1391 & -1130 & -1261\end{array}$

$\begin{array}{llll}B C & -1500 & -1300 & -1400\end{array}$

$\begin{array}{lllll}\text { KL } & -1600 & -1400 & -1500\end{array}$

$\begin{array}{llll}\text { HR } & -1800 & -1750 & -1775\end{array}$

$\begin{array}{lllll}B C & -1900 & -1700 & -1800\end{array}$

$\begin{array}{llll}\text { BC } & -2100 & -1950 & -2025\end{array}$

$\begin{array}{llll}H R & -2400 & -2300 & -2350\end{array}$

$\begin{array}{llll}H R & -2559 & -2204 & -2382\end{array}$

$\begin{array}{lllll}B C & -2573 & -2470 & -25\end{array}$

$\begin{array}{llll}\text { HR } & -2575 & -2475 & -2525\end{array}$

$\begin{array}{lllllllllllllllllllll}H R & -2620 & -2520 & -2570 & 65 / / & T A & 10 & 354.14 & 47.99 & 3.90 & 152 & 7 & 5 & 46.47 & 0.83 & * & \text { THkD } & \text { HD11-HD20 }\end{array}$

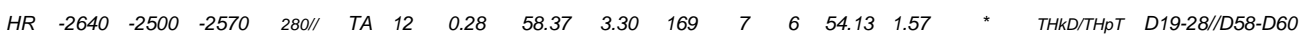

$\begin{array}{llll}\text { HR } & -2650 & -2500 & -2575\end{array}$

$\begin{array}{llllllllllll}\text { TA } & 19 & 354.10 & 51.40 & 1.12 & 253 & 15 & 14 & 45.53 & 3.89 & \text { TRM;/RM THрT/THрT } & \text { M1 - M31 }\end{array}$

$\begin{array}{llllllllllllllllll}H R & -2695 & -2535 & -2615 & 281 / 278 & T A & 35 & 2.42 & 56.66 & 1.50 & 249 & 12 & 12 & 52.92 & 4.62 & * & \text { THPT } & \text { D29-D56//D63-D78 }\end{array}$

$\begin{array}{llllllllllllllllll}\text { HR } & -2700 & -2600 & -2650 & 64 / 81 & \text { T } & 10 & 5.20 & 55.98 & 2.31 & 440 & 8 & 6 & 44.69 & 3.01 & * & \text { THDL } & \text { Yun30-Yun39 }\end{array}$

$\begin{array}{llllllllllllllllll}H R & -2700 & -2620 & -2660 & 289 / 280 & T A & 14 & 357.94 & 59.19 & 2.62 & 232 & 6 & 6 & 62.56 & 1.71 & * & \text { THPT } & \text { D80-D91//D115-D120 }\end{array}$

$\begin{array}{llllllllllllllllll}H R & -2866 & -2461 & -2664 & 1 / 76 & * & * & * & * & 5 & 53.75 & 3.34 & * & \text { THPT } & \text { Nz1-Nz4/Nz12-Nz18 }\end{array}$

$\begin{array}{llllllllllllllllll}\text { HR } & -2730 & -2650 & -2690 & 70 / 71 & \text { T } & 8 & 358.88 & 52.10 & 2.34 & 559 & 7 & 3 & 58.16 & 3.48 & * & \text { THDL } & \text { Yun22-Yun29 }\end{array}$

$\begin{array}{llllllllllllll}B C & -2750 & -2650 & -2700 & \text { T } & 8 & 1.00 & 56.20 & 2.00 & 746 & 5 & 4 & 49.62 & 0.76\end{array}$

$\begin{array}{lllllllllllllll}\text { BC } & -2770 & -2690 & -2730 & 83 / 64 & \text { T } & 7 & 1.10 & 52.10 & 4.30 & 194 & 10 & 6 & 53.41 & 4.58\end{array}$

$\begin{array}{lllllllllllllll}\text { BC } & -2875 & -2624 & -2750 & 193 / 303 & \text { TA } & 4 & 359.90 & 55.10 & 4.20 & 478 & 4 & 3 & 46.30 & 2.10\end{array}$

$\begin{array}{lllllllllllllll}H R & -2873 & -2634 & -2754 & 290 / 281 & \text { TA } & 7 & 359.58 & 51.74 & 3.40 & 316 & 6 & 5 & 50.49 & 1.81\end{array}$

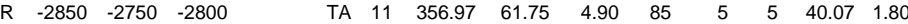

$\begin{array}{lllllllllllllll}\text { BC } & -2850 & -2750 & -2800 & 221 / 43 & \text { TA } & 10 & 6.70 & 52.40 & 2.45 & 389 & 5 & 3 & 48.67 & 1.38\end{array}$

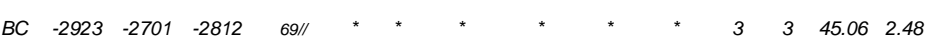

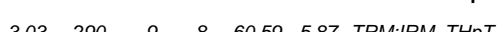

65

4-2421

-So15; So19-So24

Psh1-Psh27

1901-1912//1959-1987

PI17;1-1,8,13,18,21;3

1-Dk16

$1,5,11,15 ; 6-1,6,11$

* THDL $1295-1297$

19-B224

THDL

THDL

THpT

THPT

THKD

THPT

THDL
Yu15-Yu21/Yu40-Yu45

CA68//CA73-CA76//CA120

D121-D123//D127-D132

Str1-Str13

CA79//83-89//91//93//10//112

533-535
$7-1,6,9,11,21 ; 8-1,5,8,16$ coin\&archaeological

coins; archaeol.; graffiti;

archaeological

archaeological (ceramic)

archaeological

archaeological

archaeological

rchaeological

rchaeological

archaeological

archaeological

14C(Poz-37808,809,810)

archaeol.-before TrojaVII

14C(Bln-2571)

14C(Beta-65858;67012;67013)

archaeological

archaeological

archaeological

archaeol.\&stratigraphy

14C; relative chronology

14C\&stratigraphy

14C(BIn-1151,1255,1149, 1153)

14C(Bln-4903;4900)\&strat.\&syn.

14C\&stratigraphy

14C(BIn-1150,50A,54,54A)\&strat

relative chronology

archaeological

archaeol.\&stratigraphy

relative chronology

archaeol.\&stratigraphy

14C\&stratigraphy

archaeol.\&stratigraphy

14C(BIn-1576A)

14C\&stratigraphy

14C\&archaeol.culture

14C\&stratigraphy

4C (Bln-5231)

14C(Bln-3866;3868-71)

el.chronology\&stratigraphy

stratigraphy

14C(B/n-725-7;Bnn-1835)
239

239,502

502

370

239

197

239

239,502

197

239

197

239,502

239,502

502

239,502

502

502

239,502

239,502

239,502

239,502

502

239,502

502

239,50

239,50

197

239,502

502

239,502 
$290 \quad 42.30 \quad 26.00$ Dyadovo

$\begin{array}{llll}83 & 42.20 & 24.30 & \text { Yunatzite }\end{array}$ $\begin{array}{lll}291 & 42.30 & 26.00 \\ \text { Dyadovo }\end{array}$ $\begin{array}{lll}272 & 42.20 \quad 24.30 & \text { Yunatzite }\end{array}$ $\begin{array}{lll}221 & 42.50 & 24.90 \\ 3 a r o v k a\end{array}$ $\begin{array}{llll}317 & 42.30 & 26.00 & \text { Dyadovo }\end{array}$ $292 \quad 42.30 \quad 26.00$ Dyadovo

\section{$\begin{array}{lll}97 \quad 42.30 & 26.00 & \text { Dyadovo }\end{array}$}

$\begin{array}{lll}50 & 42.30 & 26.00 \\ \text { Dyadovo }\end{array}$

$\begin{array}{lll}350 & 42.57 \quad 26.98 \text { Dragantzi }\end{array}$

$\begin{array}{lll}68 & 42.30 & 26.00 \\ \text { Dyadovo }\end{array}$

$\begin{array}{lll}69 & 42.50 \quad 26.00 \text { Ezero }\end{array}$

$\begin{array}{lll}245 & 42.50 & 24.90 \\ & \text { Sarovka }\end{array}$

$\begin{array}{lll}359 & 42.30 & 26.00 \\ \text { Dyadovo }\end{array}$

$\begin{array}{lll}360 & 42.30 & 26.00 \\ \text { Dyadovo }\end{array}$

$67 \quad 43.10 \quad 25.50$ Hotnitza

$\begin{array}{llll}62 & 41.60 & 24.30 & \text { Trigrad }\end{array}$

$\begin{array}{lll}133 & 43.50 \quad 23.50 \text { Galatin }\end{array}$

$\begin{array}{llll}65 & 41.60 & 24.40 & \text { Trigrad }\end{array}$

$\begin{array}{lll}63 & 42.12 \quad 23.68 \text { Rebarkovo }\end{array}$

$\begin{array}{lll}57 \quad 43.10 & 23.78 \text { Krivodo }\end{array}$

$\begin{array}{lll}61 & 43.30 & 24.30 \\ & \text { Telish }\end{array}$

$6043.30 \quad 24.30$ Telish

$\begin{array}{llll}273 & 42.20 & 24.30 & \text { Yunatzite }\end{array}$

$\begin{array}{lll}288 & 41.90 & 25.00 \text { Dolnoslav }\end{array}$

$\begin{array}{lll}33 & 43.50 \quad 23.20 \text { Bagachina }\end{array}$

$\begin{array}{lll}58 & 43.20 & 23.70 \\ \text { G._Kremena }\end{array}$

$\begin{array}{lll}59 & 43.30 \quad 24.30 \text { Telish }\end{array}$

$\begin{array}{lll}45 & 43.20 & 27.90 \\ & \text { Varna }\end{array}$ 5143.0027 .50 Gol._Delchevo Multil.tell - XIII hor.upwrd - L. Eneolithic

$29743.85 \quad 26.00$ Russe

$\begin{array}{lll}49 & 43.10 & 27.00 \\ \text { Smjadovo }\end{array}$

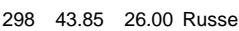

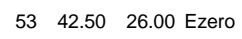

$\begin{array}{llll}254 & 43.10 & 27.00 & \text { Smjadovo }\end{array}$

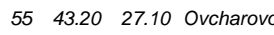

30743.7028 .60 Durankulak

30643.7028 .60 Durankulak

$\begin{array}{llll}47 & 43.20 & 27.10 & \text { Ovcharovo }\end{array}$

$299 \quad 43.85 \quad 26.00$ Russe
Multil.tell-VI hor.dwrd-sq. Q23,P23,O23 Multil.tell-XVI hor.dwrd-sq.06/05

Multil.tell-VII hor.dwrd-sq.S23,U25,019 Multil.tell-XVII hor.dwrd-Early Bronze Trench H18-3d lev.dwrd+sq.P16

Multil.tell-Supp. XIV hor.dwrd (borehole) Multil.tell-VIIIhor.dwrd-U24, V25,P20-21 til.tell-Japon sector L23

Multil.tell-IX hor.dwrd-sqs.P23,P24,P27

Early Bronze-fired remains

Multil.tell-Supp.XVI hor.dwrd (borehole) Multil.tell Ezero-XII+XIII hor.dwrd-Bronze Trench H18-4:4+5th lev.dwrd+sq.P17

Multil. tell-beg.E.Bronze-central profile Multil. tell-beg.EB-ovens2010-013/14 Vodopada -1+1I hor.dwrd-TP LE-EB Jagodinska cave-2 hor.upwrd - LE-EB Chukata-Transition period LE-EB Haramijska hole-B8/9;D3;C6-TP LE-EB Djugera - Transition period LE-EB I hor.upwrd-L.Eneolithic-KVI-Salkuca Trans.per.LE/E.Bronze-III(IV) hor.upwrd Trans. per. LE/E.Bronze-II hor.upwrd Multilevel tell-Eneolithic horizon opkite-burnt hor--KVI cult.end of Eneol. Burnt horizon - the end of Eneolith

Transition period LE/EB-(III) hor.upwrd Chernook-L.Eneolithic-KVI-burnt dwel. Eneolithic tell-I hor.dwrd-L.Eneolith Multil.tell-II hor.dwrd-Eneolithic Multil.tell-II hor.dwrd-sq.N14,M10-LE Multil.tell-XIV-XVI hor.dwrd-Early Bronze Multil.tell-III hor.dwrd-Eneolithic Eneolithic tell-XII hor.upwrd-L.Eneol. Multil.tell-IVa hor.dwrd-dwell.9a,4z-LE III Multil.tell-V hor.dwrd-dwell.9, 7-LE II Multil.tell-VIII+IX+Xhor.upwrd-LE Multil.tell-III hor.dwrd-sq.K8-L.Eneolithic
$\begin{array}{llllllllllllllllll}H R & -2866 & -2766 & -2816 & 291 / 289 & \text { TA } & 7 & 3.51 & 55.63 & 3.33 & 328 & 7 & 4 & 43.00 & 2.25 & * & \text { THPTTHPT } & \text { D133-D140 }\end{array}$

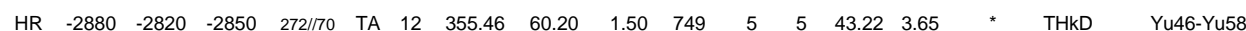

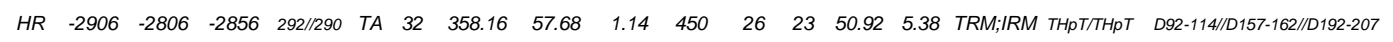

$\begin{array}{llllllllllllllllll}\text { HR } & -3000 & -2800 & -2900 & 273 / 83 & \text { TA } & 37 & 358.83 & 57.88 & 1.24 & 364 & 9 & 8 & 43.26 & 1.38 & \text { * } & \text { THkD } & \text { Yu59-Yu94/Yu104 }\end{array}$

$\begin{array}{llllllllllllllllll}B C & -3000 & -2800 & -2900 & 245 / 193 & T A & 8 & 357.20 & 56.60 & 3.30 & 276 & 6 & 6 & 38.97 & 2.07 & * & \text { THPT } & \text { CA94-102//CA114,118,119 }\end{array}$

$\begin{array}{llllllllllllllllllllllllll}H R & -3000 & -2800 & -2900 & T & * & * & * & * & * & 1 & 41.32 & 2.96 & * & T H K D & \text { DT-D14 }\end{array}$

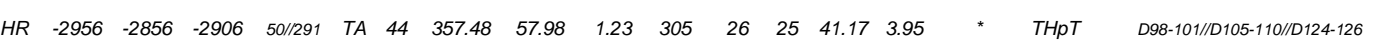

$\begin{array}{llllllllllllllllll}\text { HR } & -2975 & -2875 & -2925 & & \text { TA } & 26 & 1.11 & 58.60 & 1.47 & 374 & 12 & 9 & 40.36 & 2.57 & * & \text { THpT } & \text { D210-D249 }\end{array}$

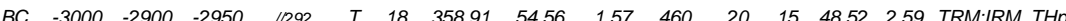

$\begin{array}{llllllllllllllllll}\text { BC } & -3000 & -2900 & -2950 & * & * & * & * & * & * & 11 & 9 & 46.78 & 2.49 & * & \text { THpT }\end{array}$

HR $\quad-3000 \quad-2900-2950$

$\begin{array}{llllllllllllllll}B C & -3100 & -2900 & -3000 & 1 / 221 & \text { TA } & 11 & 4.28 & 54.52 & 1.64 & 772 & 10 & 9 & 42.85 & 291\end{array}$

$\begin{array}{lllllllllllllll}\text { BC } & -3100 & -2900 & -3000 & \text { /150 } & \text { TA } & 61 & 0.90 & 55.40 & 1.20 & 218 & 25 & 21 & 44.67 & 2.42\end{array}$

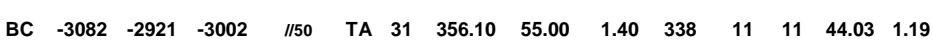

$\begin{array}{llll}B C & -3772 & -3657 & -3715\end{array}$

$\begin{array}{llll}H R & -3940 & -3706 & -3823\end{array}$

HR $\quad-4050 \quad-3900 \quad-3975$

$\begin{array}{llll}H R & -4038 & -3949 & -3994\end{array}$

BC $\quad-4160 \quad-4000 \quad-4080$

$\begin{array}{lllll}H R & -4150 & -4050 & -4100\end{array}$

$\begin{array}{lllllllllllllll}B C & -4150 & -4080 & -4115 & 59 / 61 & T & 10 & 359.03 & 54.41 & 4.33 & 126 & 8 & 8 & 46.00 & 3.02\end{array}$

$\begin{array}{lllllllllllllll}\text { HR } & -4160 & -4080 & -4120 & \text { /1272 } & \text { TA } & 8 & 15.33 & 48.07 & 2.60 & 454 & 3 & 3 & 37.68 & 1.04\end{array}$

$\begin{array}{llllllllllllll}\text { BC } & -4170 & -4070 & -4120 & \text { T } & 45 & 10.64 & 46.90 & 1.59 & 179 & 8 & 8 & 38.43 & 3.69\end{array}$

$\begin{array}{llllllllllllll}\text { BC } & -4200 & -4050 & -4125 & \text { T } & 15 & 8.85 & 50.00 & 2.51 & 232 & 9 & 7 & 49.33 & 3.62\end{array}$

$\begin{array}{llll}B C & -4210 & -4070 & -4140\end{array}$

$\begin{array}{lllll}B C & -4200 & -4100 & -4150 & / 160\end{array}$

$\begin{array}{lllllllllllllll}\text { HR } & -4200 & -4150 & -4175 & 51 / / & \text { T } & 12 & 4.98 & 49.43 & 2.70 & 254 & 12 & 9 & 45.55 & 5.36\end{array}$

$\begin{array}{lllllllllllllll}\text { HR } & -4250 & -4200 & -4225 & 35 / 52 & \text { T } & 10 & 6.65 & 45.95 & 1.90 & 646 & 11 & 11 & 39.23 & 4.93\end{array}$

$\begin{array}{lllllllllllllll}\text { HR } & -4300 & -4200 & -4250 & 298 / / & \text { TA } & 29 & 6.50 & 48.80 & 2.20 & 142 & 7 & 3 & 40.93 & 3.82\end{array}$

$\begin{array}{lllllllllllllll}\text { BC } & -4320 & -4240 & -4280 & 254 / / & \text { T } & 21 & 2.10 & 48.70 & 3.54 & 84 & 11 & 10 & 48.00 & 3.84\end{array}$

$\begin{array}{lllllllllllllll}\text { HR } & -4350 & -4250 & -4300 & 299 / 297 & \text { TA } & 16 & 8.36 & 46.59 & 2.68 & 190 & 5 & 5 & 36.14 & 1.64\end{array}$

$\begin{array}{lllllllllllllll}\mathrm{HR} & -4350 & -4290 & -4320 & 1 / 69 & \mathrm{~T} & 3 & 6.63 & 51.56 & 4.80 & 659 & 11 & 10 & 47.20 & 4.72\end{array}$

$\begin{array}{lllllllllllllll}\text { BC } & -4380 & -4280 & -4330 & 1 / 49 & \text { T } & 7 & 11.80 & 44.10 & 2.90 & 415 & 3 & 3 & 42.68 & 2.93\end{array}$

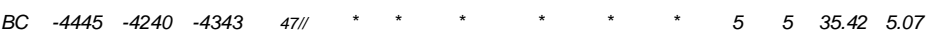

$\begin{array}{lllllllllllllll}H R & -4446 & -4257 & -4352 & 306 / / & T A & 8 & 11.60 & 47.35 & 4.37 & 162 & 8 & 4 & 42.24 & 1.01\end{array}$

$\begin{array}{lllllllllllllll}H R & -4400 & -4300 & -4350 & 295 / 307 & \text { TA } & 10 & 8.08 & 52.19 & 5.10 & 91 & 12 & 10 & 42.24 & 2.12\end{array}$

$\begin{array}{lllllllllllllll}H R & -4450 & -4350 & -4400 & 305 / 55 & \text { TA } & 9 & 6.60 & 48.40 & 5.10 & 104 & 23 & 17 & 45.23 & 4.70\end{array}$

HR $\quad-4460-4380-4420 \quad 300 / 298$ * * * * * * $\quad$ * $5 \begin{array}{llllll}5 & 5 & 42.77 & 2.80\end{array}$
THDL $\mathrm{Kr} 1-\mathrm{Kr} 32$

THDL T35-T45//T66-T68

T12-T24/T29-T34

stratigraphy

THKD Yun96-Yun103

DI1-DI47

THKD B1-B23

THDLTHPT B377-B385

THDL T1-T11//T25-T28//T46-T55 stratigraphy

THDL $\quad 320-324$

THDL 213-224

THDL 226-239

THPT Rs15-Rs44

THDL Sm1-Sm36

THPT Rs1-Rs13//Rs30-Rs34

THDL 151-157//510-527

THDL BSm37-BSm47

THDL $\quad 022-026$

THPT DK30-Dk46

$D k 36-D k 55 / / D k 82-D k 88$

THDL

THpT
01-05//012-020//027-31

Rs25-Rs29//Rs45-Rs49 rel.chronology\&stratigraphy

14C; ;rchaeol.\&strat.\&synchron.

relative chronology

14C;archaeol.\&strat.\&synchron.

stratigraphy

stratigraphy

rel.chronology\&stratigraphy

relative chronology

rel.chronology\&stratigraphy

archaeological;synchron

archaeological

14C(BIn-1156, 1841, 1786.

14C(Bln-5233),strat\&rel.chronology

\section{archaeological}

14C(PLD16899-16901)

14C(BIn-3680-3685)

14C(BIn-2247;2249;2250)

(14C) archaeological

$14 \mathrm{C}$ (Bln-3340-3345)

archaeological

archaeol.\&stratigraphy

14C(Bln-2663;2241-44;2388)

14C; rel.chronology; stratigr.

rel.chronology\&14C

archaeological

archaeological

239,502

239,502

239,502

239,502

239,502

239,554

239

239,520

239,502

239,50

239,520

39,520

502

239,502

197

239,502

502

197
239,502

239,502

502

197

197

502

502

502

chaeologica

archaeol.\&stratigraphy

archaeol.\&stratigraphy

rel.chronology\&stratigraphy

rel.chronology\& $14 \mathrm{C}$

rel.chronology\&stratigraphy

(14C) archaeol.\&stratigraphy

archaeol.\&stratigraphy

14C(BIn-1357, 1358)

14C(BIn-2121, 2111)

el.chronology\&14C\&stratigr.

(14C) stratigraphy

rel.chronology\&stratigraphy
197

502

502

197

197

239,50

239,502 239,502 
29543.7028 .60 Durankulak $\begin{array}{lll}46 & 43.30 \quad 26.60 \text { Poljanitza }\end{array}$

$\begin{array}{llll}31 & 42.40 & 25.60 & \text { Stara_Zagora }\end{array}$

$\begin{array}{lll}48 & 43.10 & 26.10 \text { Omurtag }\end{array}$

$\begin{array}{llll}351 & 43.70 & 28.60 & \text { Durankulak }\end{array}$

$\begin{array}{llll}305 & 43.20 & 27.10 & \text { Ovcharovo }\end{array}$

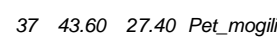

$315 \quad 42.50 \quad 25.90$ Karanovo

$\begin{array}{lll}40 & 43.30 & 26.50 \text { Lijjak }\end{array}$

$\begin{array}{llll}44 & 43.30 & 26.60 & \text { Poljanitza }\end{array}$

$\begin{array}{lll}34 & 43.50 \quad 26.50 \text { Radingrad }\end{array}$

$\begin{array}{lll}300 & 43.85 & 26.00 \\ 3 & \text { Russe }\end{array}$

$\begin{array}{lll}35 & 43.00 & 27.50 \text { Gol._Delchevo }\end{array}$

$\begin{array}{lll}287 & 42.70 \quad 23.30 \text { Sofia }\end{array}$

$\begin{array}{lll}257 & 42.17 \quad 23.10 & \text { Slatino }\end{array}$

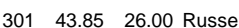

$\begin{array}{llll}39 & 43.20 & 27.10 & \text { Ovcharovo }\end{array}$

$\begin{array}{lll}38 & 43.50 \quad 23.50 \text { Gradeshnitza }\end{array}$

$\begin{array}{llll}32 & 43.20 & 27.10 & \text { Ovcharovo }\end{array}$

$\begin{array}{llll}276 & 43.20 & 27.10 & \text { Ovcharovo }\end{array}$

$\begin{array}{llll}30 & 42.17 & 23.10 & \text { Slatino }\end{array}$

$\begin{array}{llll}36 & 43.30 & 26.60 & \text { Poljanitza }\end{array}$

$\begin{array}{lll}28 & 42.00 & 23.10 \text { Blagoevgrad }\end{array}$

$\begin{array}{llll}27 & 43.40 & 24.20 & \text { Brenitza }\end{array}$

$\begin{array}{lll}26 & 41.90 \quad 23.50 \text { Eleshnitza }\end{array}$

$2542.50 \quad 26.00$ Nova_Zagor $\begin{array}{llll}260 & 41.40 & 23.30 & \text { Topolnitza }\end{array}$

$\begin{array}{lll}24 & 43.10 & 25.70 \text { Kachitza }\end{array}$

$293 \quad 43.70 \quad 25.30$ Koprivetz

$302 \quad 43.85 \quad 26.00$ Russe

$\begin{array}{lll}17 & 43.10 \quad 25.60 \text { Samovodene }\end{array}$

$\begin{array}{lll}16 & 43.30 & 26.50 \text { Podgoritza }\end{array}$

$\begin{array}{llll}263 & 43.30 & 26.20 & \text { Popovo }\end{array}$

$\begin{array}{lll}353 & 43.08 & 25.35 \text { Orlovka }\end{array}$

$\begin{array}{lll}18 & 42.60 & 25.40 \text { Kazanlak }\end{array}$

$\begin{array}{llll}23 & 43.10 & 27.40 \text { Dalgopol }\end{array}$

$\begin{array}{lll}19 & 43.10 \quad 25.60 \text { Samovodene }\end{array}$

$\begin{array}{llll}5 & 43.20 & 26.60 & \text { Ovcharovo }\end{array}$

$294 \quad 43.70 \quad 25.30$ Koprivetz

$\begin{array}{lll}355 & 43.10 & 25.60 \\ & \text { Samovoden }\end{array}$

$\begin{array}{llll}326 & 42.07 \quad 25.44 & \text { Jabalkovo }\end{array}$
Multil.tell-VI hor.dwrd-dwell.3-10-LE I Multil. tell-VII+VIII hor.upwrd-unoriented Chatalka site-KV-KVI cult.-L.Eneolithic Prehistoric tell - beg. of Late Eneolithic Multil.tell-VII hor.dwrd-ME-L.Hamandjia Multil.tell-VII hor.upwrd-M.Eneolithic Eneolithic tell - Middle Eneolithic Multil.tell-KV-KVI culture-Late Eneolithic Undigged Eneolithic tell

Multil.tell-IV hor.upwrd-M. Eneolithic Multiltell-0+1+1II hor.dwrd-Bojan IV Multil.tell-V hor.dwrd-sq.E6,N9-M.Eneol.

Itil.tell-IV hor.upwrd-M. Eneolithic Podujane-Eneolithic house No1-Vinca Multil.tell-I hor. dwrd-Early Eneolithic Multil.tell-VI hor.dwrd-sq.K6,M6, 15-ME Multil.tell-V hor.upwrd-M. Eneolithic

Eneolithic site-KV:Maritza:Gumelnitza । Multil.tell-IV hor. upwrd-Early Eneolithic Multil.tell-III hor. upwrd-Early Eneolithic II hor.dwrd-hearths,burnt equipm.-EE Multilevel tell-I+II+III hor. upwrd

Strumsko-Early Eneolithic II hor. Early Eneolithic site-KIV, KV cultures Late Neolithic site - KIV culture

\section{Industrial bakery-L.Neolithic-KIV culture} Multil.tell-III hor.dwrd-KIV-Kremenitza-LN Neolithic-VIII-th sector-KIV, Vincha A cult. IV hor. upwrd-Late Neolithic Multilevel tell-VII hor.dwrd-LN-Bojan Multil.tell-II+III+IV hor.dwrd-M.Neolithic Middle Neolithic site-KIII culture The reserve-Neolithic-KIII-KIV cult. Neolithic setlement

Multil.tell-III+IV+V hor.dwrd-Neolithic-KIII Usoeto - KIII-KIV cultures

Multil.tell-V+VI hor.dwrd-Neolithic Gorata(Ruec)-II hor.upwrd-Neolithic-KII hor. upwrd-end of Early Neolithic

\section{Multil.tell-VII+VIII hor. dwrd-Neolithic}

I hor.dwrd-the youngest hor.- E.Neolithic
$\begin{array}{lllllllllllllll}H R & -4475 & -4375 & -4425 & 351 / 306 & T A & 24 & 2.68 & 45.52 & 0.90 & 93 & 12 & 12 & 47.64 & 1.54\end{array}$ $\begin{array}{lllllllllllllllllll}H R & -4480 & -4380 & -4430 & 44 / 1 & * & * & * & * & * & * & 6 & 6 & 44.36 & 3.51\end{array}$

$\begin{array}{llllllllllllll}\text { HR } & -4550 & -4400 & -4475 & \text { T } & 8 & 8.73 & 52.89 & 4.30 & 163 & 4 & 3 & 50.50 & 3.28\end{array}$

HR $\quad-4560 \quad-4400$

$\begin{array}{lllllllllll}\text { TA } & 4 & 13.90 & 47.70 & 5.80 & 250 & 6 & 5 & 54.53 & 1.63\end{array}$

$\begin{array}{lllllllllllllll}\text { BC } & -4575 & -4425 & -4500 & \text { /1295 } & \text { TA } & 28 & 8.00 & 53.30 & 1.80 & 226 & 11 & 11 & 46.36 & 4.45\end{array}$ $\begin{array}{lllllllllllllllll}\text { HR } & -4520 & -4480 & -4500 & 39 / 47 & \text { TA } & 2 & 10.60 & 53.70 & 5.00 & 421 & 4 & 4 & 47.72 & 3.36\end{array}$

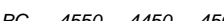

$\begin{array}{llllllllllllll}\text { HR } & -4600 & -4400 & -4500 & \text { TA } & 5 & 3.75 & 50.52 & 4.16 & 339 & 6 & 5 & 48.35 & 0.67\end{array}$

T 616.30

$\begin{array}{llll}B C & -4580 & -4440 & -4510\end{array}$

$\begin{array}{lllllllllllllll}H R & -4560 & -4460 & -4510 & 36 / 146 & T & 15 & 13.50 & 59.90 & 2.70 & 202 & 14 & 8 & 43.30 & 5.65\end{array}$

HR $\quad-4600 \quad-4450 \quad-4525$

$\begin{array}{lllllllllll}\text { TA } & 17 & 10.59 & 55.30 & 2.76 & 168 & 11 & 10 & 58.79 & 4.28\end{array}$

$\begin{array}{lllllllllllllll}\text { HR } & -4580 & -4540 & -4560 & 301 / 299 & \text { AF } & 4 & 14.50 & 52.31 & 1.64 & 3141 & 1 & 1 & 44.45 & 1.26\end{array}$

$\begin{array}{lllllllllllllll}\text { HR } & -4600 & -4550 & -4575 & 6 / 151 & \text { T } & 5 & 15.27 & 53.27 & 4.70 & 257 & 12 & 12 & 49.43 & 3.50\end{array}$

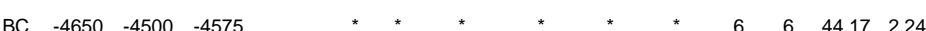

$\begin{array}{lllllllllllllll}\text { HR } & -4630 & -4530 & -4580 & 30 / / & \mathrm{T} & 10 & 14.90 & 54.50 & 3.90 & 303 & 5 & 4 & 51.06 & 1.62\end{array}$

$\begin{array}{lllllllllllllll}\text { HR } & -4650 & -4550 & -4600 & 302 / 300 & \text { TA } & 22 & 9.22 & 54.11 & 2.46 & 160 & 10 & 7 & 49.48 & 2.91\end{array}$

$\begin{array}{lllllllllllllll}\text { HR } & -4630 & -4570 & -4600 & 32 / 305 & \text { T } & 8 & 4.31 & 53.72 & 2.52 & 485 & 7 & 7 & 48.63 & 4.95\end{array}$

$\begin{array}{lllllllllllllll}\text { HR } & -4665 & -4565 & -4615 & & \text { T } & 12 & 7.11 & 54.25 & 6.10 & 51 & 7 & 7 & 49.71 & 2.94\end{array}$

$\begin{array}{lllllllllllllll}H R & -4700 & -4580 & -4640 & 276 / 39 & T & 5 & 10.30 & 44.40 & 4.10 & 356 & 6 & 6 & 51.99 & 6.24\end{array}$

$\begin{array}{lllllllllllllll}\text { HR } & -4730 & -4630 & -4680 & 5 / 32 & \mathrm{~T} & 2 & 9.80 & 46.70 & 5.00 & 900 & 2 & 2 & 51.08 & 0.91\end{array}$

$\begin{array}{lllllllllllllll}H R & -4750 & -4650 & -4700 & 1 / 257 & T & 13 & 8.60 & 45.10 & 4.30 & 93 & 8 & 8 & 42.17 & 3.52\end{array}$

$\begin{array}{lllllllllllllll}H R & -4790 & -4620 & -4705 & 1 / 44 & T & 19 & 12.10 & 52.50 & 2.00 & 273 & 14 & 6 & 47.58 & 5.29\end{array}$

$\begin{array}{llll}H R & -4981 & -4730 & -4856\end{array}$

$\begin{array}{llll}H R & -4900 & -4840 & -4870\end{array}$

HR $\quad-5130 \quad-4930 \quad-5030$

$-\mathrm{IR}, \mathrm{BC}-5150 \quad-4950 \quad-5050$

$\begin{array}{llll}B C & -5215 & -5010 & -5113\end{array}$

$\begin{array}{lllll}B C & -5218 & -5032 & -5125\end{array}$

$\begin{array}{lllllllllllllll}-5200 & -5100 & -5150 & 294 / & \text { TA } & 6 & 22.40 & 45.08 & 5.48 & 317 & 4 & 4 & 45.94 & 0.66\end{array}$

$\begin{array}{lllllllllllllll}\text { HR } & -5220 & -5110 & -5165 & 1 / 301 & \text { AF } & 2 & 22.76 & 57.70 & 3.15 & 6307 & 2 & 2 & 46.80 & 1.84\end{array}$

$\begin{array}{lllllllllllllll}\text { HR } & -5325 & -5125 & -5225 & 19 / / & \text { T } & 12 & 10.30 & 64.10 & 4.10 & 111 & 7 & 7 & 44.65 & 1.30\end{array}$

BC $\quad-5290 \quad-5190 \quad-5240$

HR $\quad-5320 \quad-5180-5250$

BC $\quad-5316 \quad-5216 \quad-5266$

\begin{tabular}{llllllllll}
\hline & 4 & 1220 & 57.60 & 370 & 624 & 7 & 7 & 46.62 & 4.48
\end{tabular}

$\begin{array}{llllllllll}\text { T } & 39 & 6.60 & 58.60 & 1.90 & 133 & 8 & 8 & 38.23 & 2.54\end{array}$

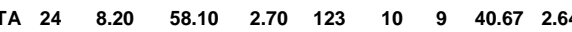

$\begin{array}{lllllllllllllll}H R & -5482 & -5053 & -5268 & 13 / / & T & 30 & 11.98 & 54.04 & 1.30 & 379 & 30 & 25 & 40.59 & 5.58\end{array}$

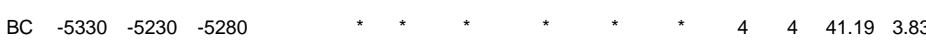

$\begin{array}{lllllllllllllll}H R & -5420 & -5220 & -5320 & 355 / 17 & T & 17 & 5.70 & 53.40 & 3.20 & 119 & 9 & 6 & 43.78 & 3.42\end{array}$

$\begin{array}{lllllllllllllll}H R & -5470 & -5326 & -5398 & 1 / 276 & T & 24 & 353.50 & 61.12 & 2.26 & 172 & 12 & 8 & 32.93 & 2.64\end{array}$

$\begin{array}{lllllllllllllll}H R & -5480 & -5380 & -5430 & 358 / 293 & \text { TA } & 8 & 348.92 & 67.60 & 2.57 & 466 & 5 & 5 & 30.66 & 0.38\end{array}$

$\begin{array}{lllllllllllllll}\text { HR } & -5520 & -5380 & -5450 & 354 / 19 & \text { T } & 11 & 7.40 & 59.30 & 2.60 & 301 & 6 & 5 & 30.91 & 2.83\end{array}$

BC $\quad-5520 \quad-5400 \quad-5460$ $\begin{array}{llllllllll}\text { TA } & 11 & 3.40 & 56.00 & 4.00 & 130 & 13 & 11 & 34.77 & 1.08\end{array}$

\begin{tabular}{|c|c|}
\hline THDL & Dk57-Dk91 \\
\hline THDL & P68-P71 \\
\hline THDL & 189-198 \\
\hline THkD & $12-161116$ \\
\hline ТНрт & Dk92-Dk130 \\
\hline ТНрТ & O9-011//OF \\
\hline THDL & B494-B514 \\
\hline THDL & $\mathrm{Kng} / / \mathrm{Kn} 14 / / \mathrm{Kn} 18 / \mathrm{Kn} 20-2$ \\
\hline THDL & L1-L14 \\
\hline THDL & P1-P32 \\
\hline THDL/THPT & B469-B493 \\
\hline THKD & Rs50-Rs53 \\
\hline THKD & $490-508$ \\
\hline THkD & Po1-Po10 \\
\hline THkD & SI21-SI33 \\
\hline THрТ & Rs54-Rs86 \\
\hline THDL & О32-О39//049 \\
\hline THDL & 779-801 \\
\hline THDL & $040-046$ \\
\hline THDL & O47-048 \\
\hline THDL & $S / 1-S / 13$ \\
\hline THDL & P33-P45//P50-P66 \\
\hline THDL & $B 11-B / 3$ \\
\hline THDL & B356-B376 \\
\hline THDL & E5-E23 \\
\hline THDL & Nz20-Nz33 \\
\hline THDLTHPT & То3-То20//KP3 \\
\hline THDL & B314-B327//K1-K13 \\
\hline THрТ & $\mathrm{Kp} 1-\mathrm{Kp} 6$ \\
\hline THkD/THрT & Rs82-Rs83 \\
\hline THkD & $C^{\prime} 30-C^{\prime} 35 / / C^{\prime} 51-C^{\prime} 58 ;$ \\
\hline THDL & $11-151116$ \\
\hline THkDTHнT & R1-R46 \\
\hline ТНрТ & Or1-Or33 \\
\hline THDL & $65-67 / / 434-476$ \\
\hline THDL & U1-U4 \\
\hline THkD & C'36-C'50//C66-C72 \\
\hline THDL & $R 1-R 39$ \\
\hline THPT & Kp7-Kp15 \\
\hline THDL & S38-S46//S51-S54 \\
\hline ТНрТ & L20-L49 \\
\hline
\end{tabular}

relative chronology

archaeo\&stratigr

archaeological

(14C) rel.chronology

relative chronology

(14C) archeol.\&stratigraphy

archaeological

el.chronology\&stratigraphy

archaeol.\&rel.chronology

archaeol.\&stratigraphy

relative chronology

rel.chronology\&stratigraphy

archaeol.\&stratigraphy

relative chronology

relative chronology

rel.chronology\&stratigraphy

(14C) archaeol.\&stratigraphy

archaeologica

stratigraphy

(14C) rel.chronology

archaeol.\&rel.chronology

(14C) archaeol.\&stratigraphy

14C(Bln-2611,12)

archaeological

relative chronology

(14C) rel.chronology

14C(BIn-3348,49,BIn-3381,82)

14C(BIn-1685,86,87)

relative chronology

rel.chronology\&stratigraphy

rel.chronology\&stratigraphy

relative chronology

relative chronology

14C(KN-5766, 5769)

14C(B/n-729)

relative chronology

rel.chronology\&stratigraphy

$14 C(B \ln 1544,1620,2030,32)$

elative chronology

relative chronolog

archaeological
239,502

197

502

502

239,502

239,502

502

197

197

197

197

197

197

239,502

197

239,502

239,502

197

502

239,50

239,502

502

197

502

239,502

197

197

239,502

239,502

239 
$\begin{array}{lll}6 & 43.00 & 27.50 \\ \text { Gol._Delchevo Multilevel tell-I hor.upwrd - Neolithic }\end{array}$ $\begin{array}{lll}262 & 43.30 & 26.20 \\ \text { Popovo }\end{array}$

$\begin{array}{lll}14 & 42.10 \quad 23.10 \text { Balgarchevo }\end{array}$

$\begin{array}{lll}13 & 42.60 \quad 25.40 \text { Kazanlak }\end{array}$

$\begin{array}{lll}358 & 43.70 & 25.30 \\ & \text { Koprivetz }\end{array}$

35443.1025 .60 Samovoden

$\begin{array}{lll}259 & 42.50 \quad 25.90 \text { Karanovo }\end{array}$

$8 \quad 41.80 \quad 23.60$ Dobrinishte

1043.1025 .60 Samovodene

$9 \quad 43.1025 .60$ Samovodene

742.5025 .70 Stara_Zagora

$\begin{array}{lll}324 & 42.30 & 22.67 \text { Kustendil }\end{array}$

$\begin{array}{lll}11 & 42.40 & 23.10 \text { Galabnik }\end{array}$

$\begin{array}{lll}261 & 41.50 \quad 23.50 \text { Kovatchevo }\end{array}$

$\begin{array}{lll}4 & 42.70 & 23.30 \text { Sofia }\end{array}$

$\begin{array}{lll}241 & 42.70 \quad 23.30 \text { Sofia }\end{array}$

$2 \quad 42.00 \quad 24.10$ Rakitovo

$\begin{array}{lll}139 & 42.07 \quad 25.44 \text { Jabalkovo }\end{array}$

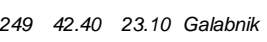

$\begin{array}{llll}242 & 42.70 \quad 23.30 \text { Sofia }\end{array}$

$\begin{array}{lll}243 & 41.90 & 23.50 \text { Eleshnitza }\end{array}$

$\begin{array}{llll}246 & 42.30 & 23.20 & \text { Krajnitzi }\end{array}$

$250 \quad 42.40 \quad 23.10$ Galabnik

$24741.50 \quad 23.50$ Kovatchevo
The reserve-Neolithic - KII culture

Multil.tel-VIII IX hor dwrd end ENeolith

\section{Thor.upwrd-Early Neolithic}

Multil.tell-IX hor. downward-Neolithic

Multilevel tell-KII-Early Neolithic

Early Neolithic (second half)

Multilevel tell-burnt dwell.-Neolitthic

Multilevel tell-XI hor. dwrd-Neolithic

Okruzhna hospital-KII cult.-burnt dwell.

Early Neolithic site Piperkov chiflik

VIII hor.upwrd-2-2.25m.depth-Neolithic

Remains of fire-sq.K13-20-KI culture

Printing house-Neolithic-KI-Starchevo A

Slatina-E.Neolithic house-the fire

Makakov bridge - Starchevo I-KI culture

"l hor.dwrd-E.Neolithic-site's oldest hor.

VIlhor.upwrd-2.6m.depth-E. Neolithic

Slatina-baked floor-E.Neolithic house

Early Neolithic-KI culture-unoriented

Early Neolithic - beginning

I hor.upwrd-4.5m.depth-E.Neolithic

Earliest stage of E.Neolithic site-sect.L $\begin{array}{llll}\text { BC } & -5520 & -5420 & -5470\end{array}$

KL $\quad-5530 \quad-5430 \quad-5480$

$\begin{array}{llll}\text { HR } & -5520 & -5450 & -5485\end{array}$

$\begin{array}{lllll}H R & -5530 & -5450 & -5490\end{array}$

$\begin{array}{llll}\text { HR } & -5550 & -5450 & -5500\end{array}$

$\begin{array}{lllll}\text { HR } & -5620 & -5460 & -5540\end{array}$

BC $\quad-5600 \quad-5500 \quad-5550$

$\begin{array}{lllll}H R & -5625 & -5490 & -5558\end{array}$

$\begin{array}{lllll}H R & -5670 & -5530 & -5600\end{array}$

$\begin{array}{lllll}H R & -5720 & -5600 & -5660\end{array}$

$\begin{array}{lllll}B C & -5742 & -5617 & -5680\end{array}$

$\begin{array}{llll}B C & -5800 & -5600 & -5700\end{array}$

HR $\quad-5784 \quad-5663 \quad-5724$

$\begin{array}{lllll}\text { BT } & -5879 & -5569 & -5724\end{array}$

$\begin{array}{llll}\text { BC } & -5830 & -5630 & -5730\end{array}$

$\begin{array}{llll}B C & -5740 & -5730 & -5735\end{array}$

BC $\quad \begin{array}{rlll}-5790 & -5690 & -5740\end{array}$

$\begin{array}{lllll}B C & -5850 & -5650 & -5750\end{array}$

$\begin{array}{lllll}B C & -5834 & -5674 & -5754\end{array}$

$\begin{array}{lllll}B F & -5802 & -5717 & -5760\end{array}$

$\begin{array}{lllll}B C & -5836 & -5717 & -5777\end{array}$

$\begin{array}{lllll}B C & -5870 & -5710 & -5790\end{array}$

$\begin{array}{lllll}B C & -5991 & -5841 & -5916\end{array}$

KL $\quad-5999 \quad-5896 \quad-5948$
//35 *

$\begin{array}{lllllll}* & * & * & 8 & 7 & 36.30 & 5.52\end{array}$

$\begin{array}{lllllllllll}18 & T & 11 & 358.94 & 54.53 & 2.50 & 311 & 11 & 10 & 44.26 & 4.14\end{array}$

$\begin{array}{lllllllllll}/ / 294 & \text { TA } & 8 & 4.27 & 64.20 & 2.08 & 707 & 5 & 5 & 34.89 & 0.91\end{array}$

$\begin{array}{llllllllll}T & 11 & 5.20 & 59.70 & 3.50 & 174 & 5 & 4 & 47.00 & 3.65\end{array}$

$\begin{array}{lllllllllll}\text { TA } & 26 & 359.50 & 63.30 & 1.60 & 292 & 8 & 7 & 52.43 & 2.32\end{array}$

$\begin{array}{llllllllll}\text { TA } & 12 & 356.80 & 65.50 & 3.10 & 187 & 7 & 7 & 41.41 & 1.49\end{array}$

$\begin{array}{lllllllllll}9 / 354 & T & 12 & 0.80 & 61.40 & 2.60 & 271 & 10 & 10 & 37.17 & 2.54\end{array}$

$\begin{array}{lllllllllll}1 / 10 & T & 16 & 355.00 & 51.80 & 2.70 & 192 & 7 & 5 & 41.43 & 2.59\end{array}$

$\begin{array}{llllllllll}T & 30 & 351.90 & 65.17 & 3.10 & 72 & 13 & 13 & 48.63 & 4.12\end{array}$

$\begin{array}{llllllllll}T A & 15 & 348.20 & 59.30 & 2.00 & 370 & 22 & 19 & 44.04 & 4.96\end{array}$

$\begin{array}{llllllllllll}249 / / & T A & 14 & 355.90 & 60.90 & 2.40 & 255 & 16 & 12 & 59.03 & 2.80\end{array}$

$\begin{array}{lllllllllll}47 / / & T A & 10 & 355.50 & 63.80 & 3.30 & 205 & 6 & 6 & 37.69 & 4.32\end{array}$

* * * * * * $3 \begin{array}{llllllll} & 3 & 44.88 & 0.88\end{array}$

$\begin{array}{llllllllll}\mathrm{T} & 10 & 340.70 & 57.10 & 4.80 & 101 & 11 & 11 & 45.27 & 2.00\end{array}$

* * * * * * $3 \quad 3 \quad 52.363 .96$

$\begin{array}{llllllllll}T A & 21 & 359.50 & 62.40 & 2.50 & 167 & 23 & 22 & 43.39 & 4.03\end{array}$

$50 / 111$ * * * * * * * $\quad \begin{array}{ccccccc}5 & 4 & 63.26 & 0.84\end{array}$

$\begin{array}{llllllllll}T A & 6 & 345.25 & 59.88 & 4.70 & 204 & 9 & 9 & 62.00 & 1.86\end{array}$

* * * * * * $6 \begin{array}{llllll} & 5 & 55.42 & 2.08\end{array}$

$\begin{array}{llllllllll}A F & 4 & 335.53 & 63.63 & 4.80 & 367 & 5 & 5 & 56.53 & 4.52\end{array}$

$\begin{array}{llllllllllll}1 / 249 & T A & 4 & 340.61 & 51.50 & 4.96 & 344 & 7 & 4 & 46.83 & 2.36\end{array}$

$\begin{array}{lllllllllll}\text { //261 } & T A & 41 & 350.80 & 64.00 & 1.60 & 183 & 19 & 15 & 53.72 & 2.46\end{array}$
THDL $\quad 510-518$

THKD/THPT R47-R76

THKD BI 4 - BI 9

THDL $424-443$

THрT Kр16-Kр23

THDL S59-S6//S73-S76

THKD Kn23-Kn48

THKD Db1-Db19

THDL S24-S36//S47-S50

THDL $\quad S 1-S 23$

THDL Sz1-Sz52

THPT PCh1-PCh23

THKD/THDT G/2-G/9//G/21-G/32

THDL Ko2-Ko14

THDL Sf1-Sf6

THKDTHрT $\operatorname{Sin} 1-\operatorname{Sin} 21$

THDL B386-B397

THPT L15-L27/L50-L67

THKD/THPT G/33-G/36

THKD SIn11-Sln 31

THKDTTHDT E1-E4

THKD/THPT KRN1-KRN4

THKDITHPT G/12-GI2O

THPT Ko15-Ko70 rel.chronology\&stratigraphy

197

relative chronology

14C; rel.chronology

relative chronology

relative chronology

relative chronology

relative chronology

14C(Bln-3785,86)

relative chronology

rel.chronology\&stratigraphy

14C(BIn-1250,52;1163,64,64A)

Rel.chronology ceramic features

$14 \mathrm{C}$ (Bln-3576,4091,92,93,GrN-19783)

$14 C(L y-6553,54)$

relative chronology

archaeological

relative chronology

stratigraphy

(14C) stratigraphy

14C(Bln3434-43;Bln3504,3555)

$14 C(B / n-3237-42 ; B(n-3244,45)$

relative chronology

$14 C$ (BIn-3579,79H,80,81,82)

14C(GrA-44365,581;OXA-20247)
502

197

502

239

239,502

239,502

239,502

239,502

371

239,502

239,502

502

239,502

239,502

239,502

239,502

239,502

239,502

172 